ח

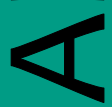

n

Ш

Z

O

$\underline{-}$

$F$

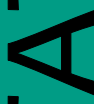

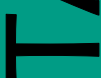

ه

Ш

n

n

$\overline{0}$
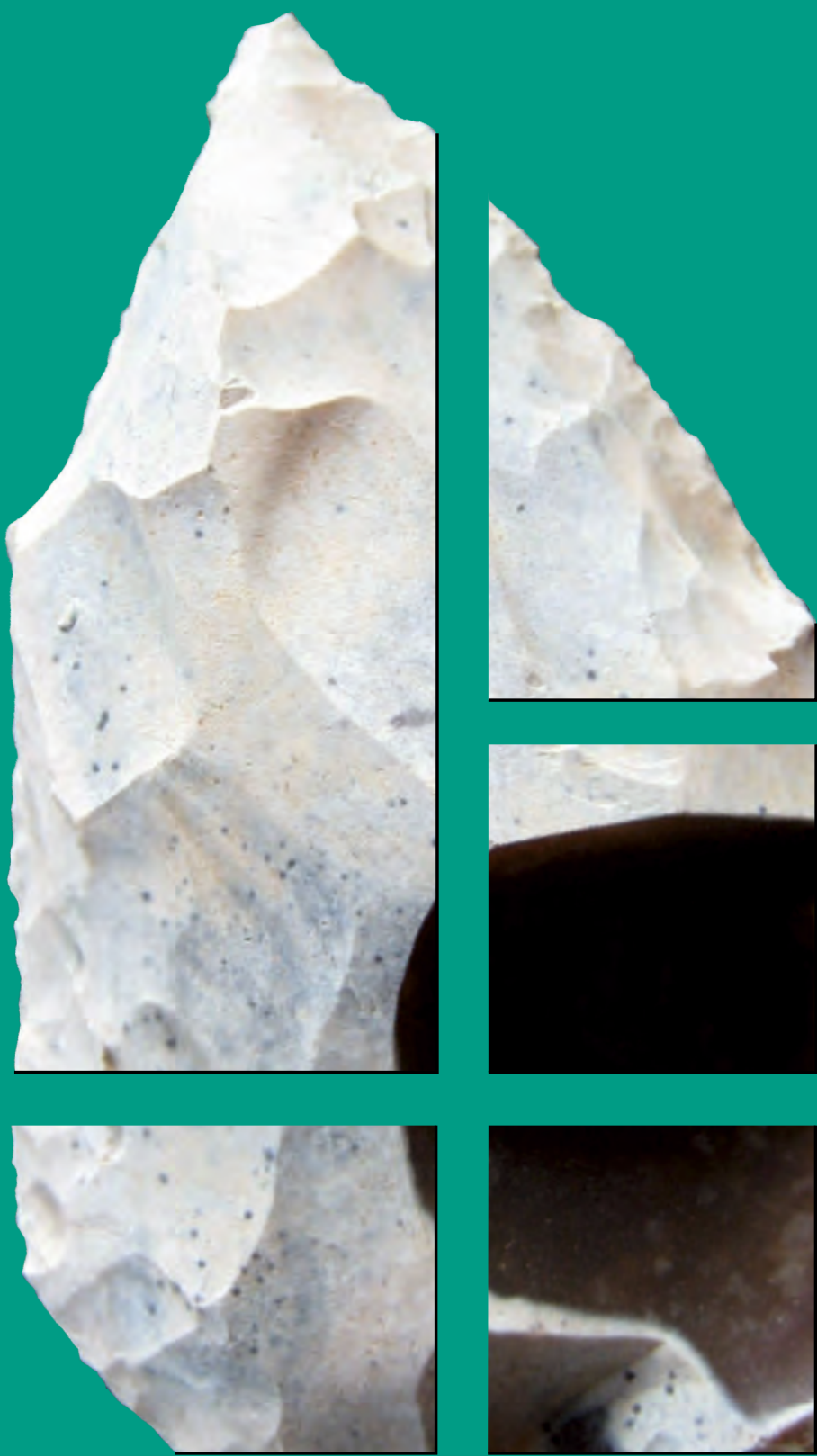

Ser. 3. No.9.| 2021 


\section{Dissertationes Archaeologicae ex Instituto Archaeologico}

Universitatis de Rolando Eötvös nominatae

Ser. 3. No. 9.

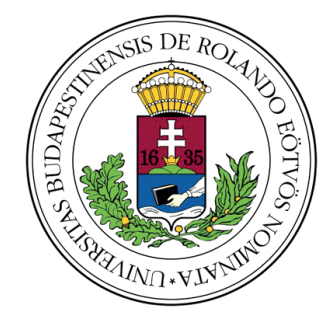

Budapest 2021 


\section{Dissertationes Archaeologicae ex Instituto Archaeologico Universitatis de Rolando Eötvös nominatae}

Ser. 3. No. 9.

Editor-in-chief

Dávid BARTus

Editorial board

László Bartosiewicz (Stockholm University, Stockholm)

Ondřej Chvojкa (University of South Bohemia, České Budějovice)

Zoltán Czajlik (Eötvös Loránd University, Budapest)

Mario Gavranović (Austrian Arhaeological Institute AAS, Vienna)

Hajnalka Herold (University of Exeter, Exeter)

Klára Kuzmová (University of Trnava, Trnava)

Tina Milavec (University of Ljubljana, Ljubljana)

Gábor V. Szabó (Eötvös Loránd University, Budapest)

Tivadar VIDA (Eötvös Loránd University, Budapest)

Technical editor

Gábor VÁcZI

Proofreading

Eszter TímÁr

Strobe DrIVER

Borbála MoHÁcsI

Fruzsina NÉMETH

Eli J. S. WeAVERDYCKE

Aviable online at http://ojs.elte.hu/dissarch

Contact: dissarch@btk.elte.hu

ISSN 2064-4574 (online)

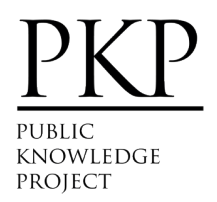

(c ELTE Eötvös Loránd University, Institute of Archaeological Sciences

Layout and cover design: Gábor Váczi

Budapest 2021 


\section{CONTEnTs}

\section{ARTiCles}

Attila PÉNTEK - Norbert FARAgó

Palaeolithic and Mesolithic assemblages from Tunisia

Attila PÉNTEK - Norbert FARAGó

Some remarks on a German chipped stone lithic assemblage of uncertain origin in the collection of the Institue of Archaeological Sciences, Eötvös Loránd University

László Gucsi

Technological observations on a Late Copper Age ceramic assemblage

from Hódmezővásárhely-Kopáncs-Olasz-tanya, Hungary

János Gábor TARBAY

101

A Koszider Period Sword from Tornyospálca-Sírkútgaz (Szabolcs-Szatmár-Bereg County, Hungary)

Ábel GARCZIK

Dolia in the Middle La Tène Period of the Carpathian Basin in the light of new finds from Perkáta-Nyúli-dűlő

Lajos JuHÁsz

An exceptional Sarmatian cast medallion with star and crescent

Gabriella G. DeLBó

New data on the Pannonian glazed casserole handles

Csilla SÁró

The fibula production of Brigetio: Model, semi-finished products, and failed castings

Anita BENES

New data on the capacity of the Roman aqueduct of Brigetio

Melinda SzABó

Status or Role? Differences between the Social Status and Role in Brigetio

Krisztina HoppáL

Roman engraved gems from Southeast Asia 


\section{FiELD REPORTS}

Bence SIMON - Ferenc BARNA

Another barrel-lined well a road section and late Roman graves from Brigetio

Rita RAKONCZAY

Trial excavations in mediaeval churches of Kishartyán, Kisterenye, Mátranovák and Szuha in Nógrád County 2021

\section{Thesis Review Articles}

Tamás KEszi

The change of the pottery style of the Mako and Nagyrév cultures in the Early Bronze Age:

The settlement in Iváncsa-Lapos

Linda Dobosi

Building techniques and building materials in Brigetio:

With the virtual reconstruction of House I/a of the civil town of Brigetio

Csilla SÁRó

Tradition and Romanization by the attire of the Eraviscus tribe 


\title{
Roman engraved gems from Southeast Asia
}

\author{
Krisztina HoppáL \\ MTA - ELTE - SZTE Silk Road Research Group, \\ Eötvös Loránd Research Network \\ kinaicsereprogram@gmail.com
}

Received 19 December 2021 | Accepted 28 December 2021 | Published 2 March 2022

\begin{abstract}
In recent years our understanding of ancient maritime networks has evolved significantly. Extensive international joint excavations and a heightened interest in collecting ancient objects among local people have altogether yielded a significant number of Roman artefacts both from Mainland and Island Southeast Asia. Regarding the types of these Roman objects, a quantity of engraved gems bearing western characteristics emerges from the collected materials thereby suggesting recognition and possibly even some degree of appreciation by the local cultures.

This paper examines the categories and distribution of Roman engraved gems discovered in Southeast Asia, and aims to show possible imprints on forming evaluation/acceptance of these non-local goods by the receiving cultures.

Keywords: Roman Empire, engraved gems, Southeast Asia, cross-cultural interactions, Maritime Silk Roads
\end{abstract}

\section{Introduction}

Archaeology of Southeast Asia had long been on the periphery of research on ancient maritime networks, which traditionally focused on Indian Ocean contacts, and rarely looked beyond the Indian subcontinent. Along with the shift from the western centered paradigm in humanities, a number of regional studies have undergone exponential growth that have brought regions between the Bay of Bengal and the South China Sea to be recognized as significant factors of ancient intertwined networks connecting East and West.

International joint cooperation, in conjunction with local field projects renewed the long-existed interest in collecting Roman finds among local people. Among these exotic objects, engraved gems emerge both by quantity and quality. These artefacts were typically made of various types of natural stones, and as such preservation has not been an issue. Concomitant to and judging from the concentration of Roman and western engraved gems particularly in southern Thailand (and partly southern Myanmar) alludes that the possession of such stones to having been wide-spread in those regions.

In the Roman Empire engraved gems belonged to private individuals and representations on them were dictated by private choice giving these objects both human and historic appeal. ${ }^{1}$ In Southeast Asia number of Roman and western engraved gems suggests a certain degree of recognition along with possible appreciation towards such materials which bring special significance to these artefacts and might also allow possible insights into the local cultural fabric of their receiving communities and as such stresses the need for their further analyzes.

RICHTER 1968, 279. 
In this manner, the paper aims to offer a regional synthesis by examining the categories and distribution of Roman engraved gems discovered in Southeast Asia. To do so, it presents the relevant parts of a techno-stylistic analytical frame which has been invented by B. Bellina, L. Dussubieux and the author in order to interpret and discuss Asia-discovered materials in terms of levels of interactions (Mediterranean objects or locally produced object with one or different Mediterranean elements). This methodology helps to identify western style in local contexts, and uncovers potentially locally-regionally made 'hybridized' products. Engraved gems will be analyzed following these categories, which enables the differentiation between non-local materials from hybrid craft systems revealing local adoption and adaptations. It allows to get more insights into the social life of different engraved gems, through which it might also be possible to uncover aspects of perceptions regarding western-connected engraved gems in Southeast Asian communities.

\section{Analytical frame}

Links between the Mediterranean world and Asia can be examined via different categories of artefacts based on the formalization focusing on style and technique. These categories are:

- Objects of Mediterranean origin representing items whose raw material, techniques and styles are Mediterranean,

- Locally made objects integrating western (which in context of the paper indicates Roman in a narrow sense) element(s) to varying degrees.

Both categories can be divided into several subcategories, however regarding Southeast Asia found glyptics bearing western characteristics, examples of two subcategories can be seen in particular. One of these subcategories is the objects of Mediterranean origin arriving via indirect contacts, ${ }^{2}$ principally through the Indian subcontinent. In contrast of direct contacts, indirect contacts are more passive, a series of middlemen were involved in transferring the objects, and the final destination was most likely only determined by (one of) these mediators. These indirect links do not imply interactions with the Roman Empire. The other subcategory which can be particularly seen in case of Southeast Asia discovered engraved gems with western characteristics is the category of western style artefacts made of local (in this case mostly regional or continental) raw material and techniques. This category indicates either direct or indirect links with the Mediterranean world (depending whether the examined objects were made in the Indian subcontinent or beyond), but the aforementioned does not imply necessarily sustained or close interactions, nor real transfer. ${ }^{3}$

\section{Limits of identifications}

Differentiation between the above subcategories requires a careful iconographical and technological analysis as depending on the degree and quality (technological and artistic abilities) of integration of western elements, the resulting objects might have a great resemblance to the Roman originals. Therefore, it is not surprising that it had been very tempting to connect these engraved gems to the Roman Empire regardless of their origin.

3 For these techno-stylistic categories applied to visualize different levels of interactions between the Mediterranean world, the Indian subcontinent, Southeast Asia and China see: HoppÁL et al. forthcoming. 
Studying these engraved gems is also complicated by the lack of secure archaeological context. Most of these intaglios and cameos are in private collections, or have been looted and kept in villagers' collections. Although most objects presented below have been claimed to be discovered at ancient entrepôts in Thailand and Vietnam, the possibility that the looters' connected these artefacts to wellknown archaeological sites in order to increase marketability of their merchandise cannot be ruled out. Even if the provenance from the claimed site is not doubted, the exact findspot, archaeological feature, and stratigraphy is still unknown. This complicates further interpretations, and makes details of their possible receptions by local communities unclear. Because of lacking solid archaeological context, the arrival and burial times of these items are also dubious. Engraved gems were popular type of portable antiquities; thus, it is possible that some of them might have been post-ancient, or even modern time arrivals - as it might be the case for some Roman coins discovered in Southeast Asia. ${ }^{4}$ Hence, the tentative production dates do not necessarily informative regarding their burial time.

\section{Gems of Mediterranean origin from Southeast Asia}

Although vast majority of the Southeast Asia found engraved gems integrating western elements to varying degrees are in private collections, thus without secure archaeological context and solid information on their findspot, most can be linked to exact sites with some degree of certainty. Thailand has yielded a number of such artefacts, among which the most significant amount has been claimed to be discovered in Khlong Thom (Krabi, Thailand). ${ }^{5}$ At least four of these Khlong Thom connected items are presumably objects of Mediterranean origin. ${ }^{6}$

One of the most recognized engraved gems in the literature is the carnelian intaglio depicting Fortuna, formerly held at the Wat Khlong Thom museum (Fig. 1,3). ${ }^{7}$ The standing female figure is wearing a chiton (a long tunic) and himation (long cloak), and holding a cornucopia (horn of plenty) and a rudder, a corn-ear and a poppy-head, and is presumably dated to the late $1^{\text {st }}$ to $2^{\text {nd }}$ century AD. A somewhat similar figure - but might be another deity - was reportedly discovered in southern Myanmar (inv. no MYM 026; Fig. 6,6), ${ }^{8}$ although further analyses would be needed to confirm its place of production. Another often cited item is an oval carnelian intaglio bearing the representation of two fighting cocks, held in the collection of the Wat Khlong Thom museum (Fig. $1,1),{ }^{9}$ again presumably dated to the late $1^{\text {st }}$ to $2^{\text {nd }}$ century $\mathrm{AD}$. The motif of fighting cocks was very popular in the classical world, ${ }^{10}$ and individual cocks (the animal often associated with gods, such as Mercurius or Sol/Helios) were also often depicted in a standing position. ${ }^{11}$ It is interesting to note that other gems featuring individual standing birds, possibly cocks, can be found in the collection of the Suthi Ratana Foundation, reportedly discovered in Bang Kluai Nok and Khlong Thom. ${ }^{12}$

4 For examples see: Hoppál et al. 2018.

5 See e.g., Pongpanich 2013, 137-151.

6 Borell et al. 2014, 101-102, Figs 2-4. The following identifications and dates are all based on B. Borell's re-examinations.

7 E.g., Bronson 1990, 217; Glover 1990, 8; Veraprassert 1992, 156; Glover 1996a, 374, Fig. 5; Glover 1996b, 65; Bellina 1998, 97; Bouzek - OndŘejová 2010, 8, Fig. 1; Noonsuk 2012, 50, 52; Borell et al. 2014, 101, Fig. 3.

8 PongPanich 2019, 266. Also: http://www.bunchar.com/version1/index.php/beyondbeads/1682-201704186-time-to-reconsider-the-beads-of-myanmar (Lat accessed: 05. 07. 2021)

9 E.g., Bronson 1990, 217; Glover 1996a, 374, Fig. 5; Bellina 1998, 97; BouZeK - OndřEjovÁ 2010, 9, Fig. 2; Noonsuk 2012, 50-51; Borell et al. 2014, 101, Fig. 2; LiuchaichāN 2019, 37.

10 See e.g., GeszTelyi 2001, 48, Cat. 54.

11 See e.g., Gesztelyi 2005, 17; Bouzek - Ondřejová 2010, 9; Cravinho 2017, 214-215.

12 Pongpanich 2013,145, 171. See also: Wright 2009, 55, Figs 3-5. 

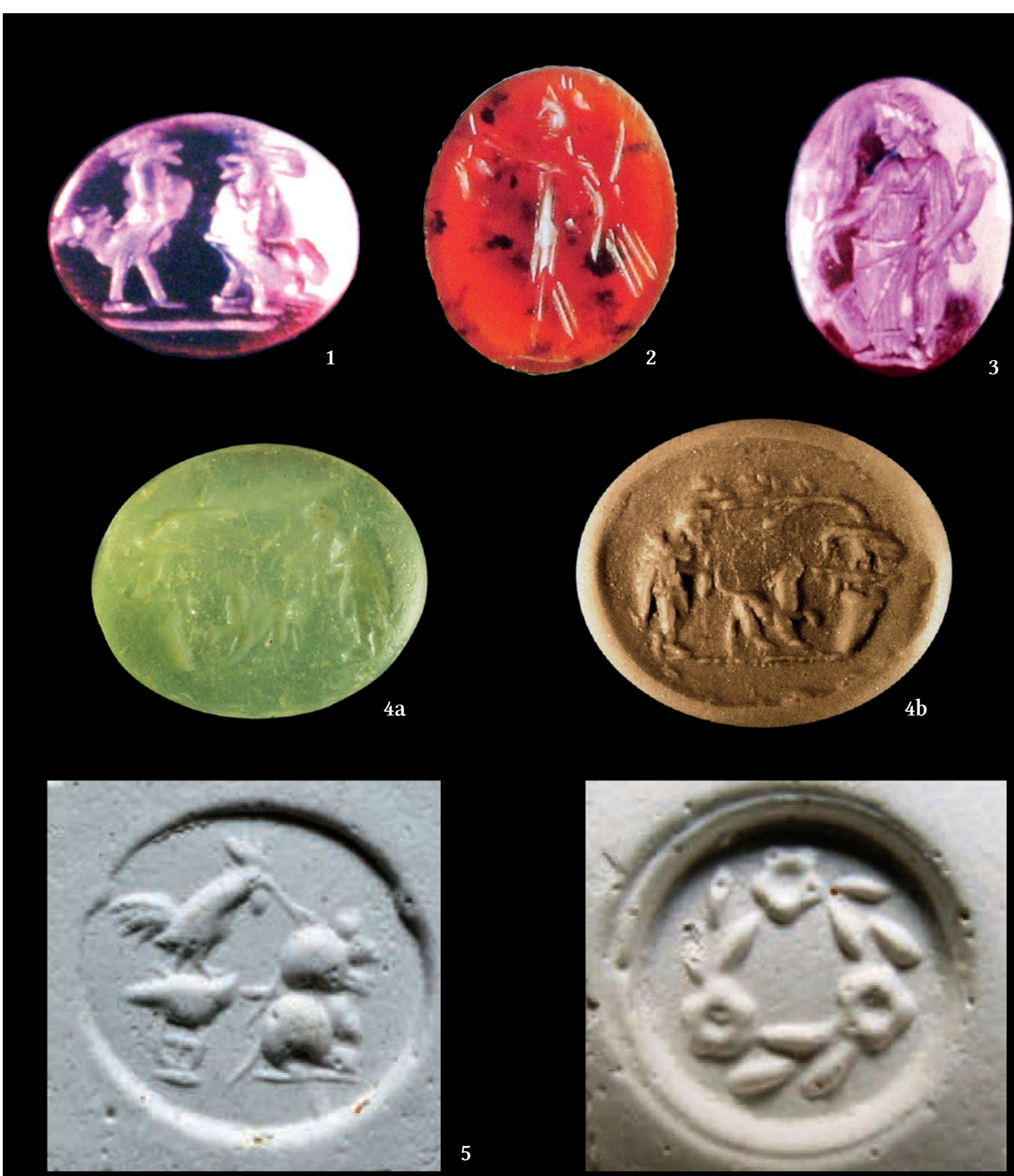

6

Fig. 1. Roman engraved gems from Southeast Asia (already re-examined). (All images are in individual size).

However, their origin is yet to be identified. A third carnelian intaglio now in the collection of the Suthi Ratana Foundation (inv. no. KLP 345) is depicting a young nude male figure, supposedly a satyr (Fig. 1,2), ${ }^{13}$ with two-pointed goat horns on his head, and a nebris (fawn skin) hanging over his arm. In his raised hand he is holding a bunch of grapes, in the other hand a lagobolon or pedum (hunter's stick). The artefact is presumably dated to the mid- $2^{\text {nd }}-$ early $3^{\text {rd }}$ century AD. V. M. Di Crocco

E.g., Bronson 1990, 217; Glover 1996b, 65; Wright 2009, 47; Chaisuwan 2011, 85; Pongranich 2013, 145; Bouzek - Ondřejová 2010, 10, Fig. 3; Noonsuk 2012, 50-51; Krairiksh 2012, 43, Fig. 1,10; Borell et al. 2014, 101-102, Fig. 4a-b; LAPTEFF 2016, 301, 304, 307, Fig. 13. (In Lapteff's publication all gems regardless their type have been referred to as cameos.) In the literature interpretation of the young Perseus holding the head of Medusa has also been suggested. 
mentions an 'almost identical object' made of glass from Hmawza (Srikshetra), Myanmar, although the interpretation of the scene is different, i.e., Perseus holding the head of Medusa (Fig. 6,7)..$^{14}$ The fourth, presumably Roman object is an oval glass intaglio portraying a bucolic scene of a bearded herdsman and his dog (Fig. 1,4a-b). On the left a rock with an eagle and its prey on it, and a tree with horizontally bended branches are depicted..$^{15}$ However other interpretation i.e., representing the abduction of Ganymede is also existing. ${ }^{16}$ The stone original can probably be dated to the early $1^{\text {st }}$ century onwards, which serves as a terminus post quem for the glass intaglio. The same private collection is holding another engraved gem with the motif of a rural scene reportedly found in Phu Khao Thong. This case the herdsman is represented with four horses (Fig. 5,5). ${ }^{17}$ However its possible place of production is yet to be identified.

Other engraved gems from Phu Khao Thong and the neighboring Bang Kluai Nok (Ranong, Thailand) can be connected to the Roman Empire with more certainty. Such as the agate intaglio representing a satyr with a nebris who is playing a double flute (Fig. 2,2) ${ }^{18}$ These figures from the Dionysiac circle often reflect on a life of bucolic abundance, and often appear on gems while making music or dancing. ${ }^{19}$ The Phu Khao Thong piece can presumably, be dated between the late $1^{\text {st }}$ century $\mathrm{BC}$ and the $1^{\text {st }}$ century $\mathrm{AD}$. Another, this time carnelian piece with similar dating was reportedly found in Bang Kluai Nok. ${ }^{20}$ The gem portrays a bust of a young satyr in profile with a nebris on his shoulders (Fig. 2,3). The figure is looking ahead with a wide-open eye, his nose is short and straight, his mouth is slightly open, his rounded head is enwreathed by rich, curly hair. The modelling is vivid and delicate. Such satyr busts in a similarly vivid style were discovered from different locations in Hungary, however those were presumably produced between the late $2^{\text {nd }}$ and early $3^{\text {rd }}$ century $\mathrm{AD} .^{21}$ The collection of the Suthi Ratana Foundation also contains another engraved gem with a profile bust of a young figure from the same location (Fig. 5,3a-b), ${ }^{22}$ although further analyses would be needed to confirm its identification and origin.

One of the most exquisite examples of Southeast Asia found engraved gems is the cameo fragment from Bang Kluai Nok (Fig. 2,4), ${ }^{23}$ presumably dated to the late $1^{\text {st }}$ century BC - early $1^{\text {st }}$ century AD. Only the lower edge of the layered sardonyx object remained, representing the lower body of two male figures on an uneven ground. The one on the left is portrayed in a moving position, his curly tails suggest the identification of a satyr. While the standing figure on the right might be another satyr or perhaps Dionysos/Bacchus himself.

The same private collection is holding another delicate gem, an oval amethyst intaglio, reportedly from Tha Chana (Surat Thani, Thailand; Fig. 2,1). ${ }^{24}$ The object represents a nude figure of Dionysos/ Bacchus draped in a long cloak, in one hand he is holding a thyrsus (a long wand or staff covered

\section{Di Crocco 1996, 165, Fig. 7.}

Borell et al. 2014, 104, Fig. 8a-b.

Pongpanich 2013, 148; Wright 2009, 48, Figs 5-6; Lapteff 2016, 301, 304, 308.

Wright 2009, 52, Figs 1-2; Pongpanich 2013, 158; Lapteff 2016, 301, 304, 309, Fig. 17.

Borell 2015, 51, Fig. 10; Borell 2017a, 25-26, Fig. 5; Borell 2019, 63, Fig. 7; Pongranich 2019, 250.

GesZTelyi 2001, 15.

Borell 2015, 51, Fig. 10; Borell 2017a, 25-26, Fig. 5; Borell 2019, 63, Fig. 7; Pongpanich 2019, 250.

Gesztelyi 1978; Gesztelyi 2001, 45, Cat. 39.

Wright 2009, 53, Figs 3-4; Pongpanich 2013, 171; Lapteff 2016, 301, 304, 310, Fig. 18.

23 E.g., Wright 2009, 57, Figs 1-2; Pongpanich 2013, 171; Borell et al. 2014, 103-104, Fig. 1; Borell 2015, 52, Fig. 11; Lapteff 2016, 301, 304, 310, Fig. 18; PongPanich 2019, 250.

24 E.g., Noonsuk 2012, 53; Pongpanich 2013, 105; Borell et al. 2014, 102, Fig. 6a-b; Borell 2015, 51, Fig. 10; Lapteff 2016, 301, 304, 307, Fig. 12; Borell 2017a, 25-26, Fig. 5; Borell 2019, 63, Fig. 7; PongPanich 2019, 267. 


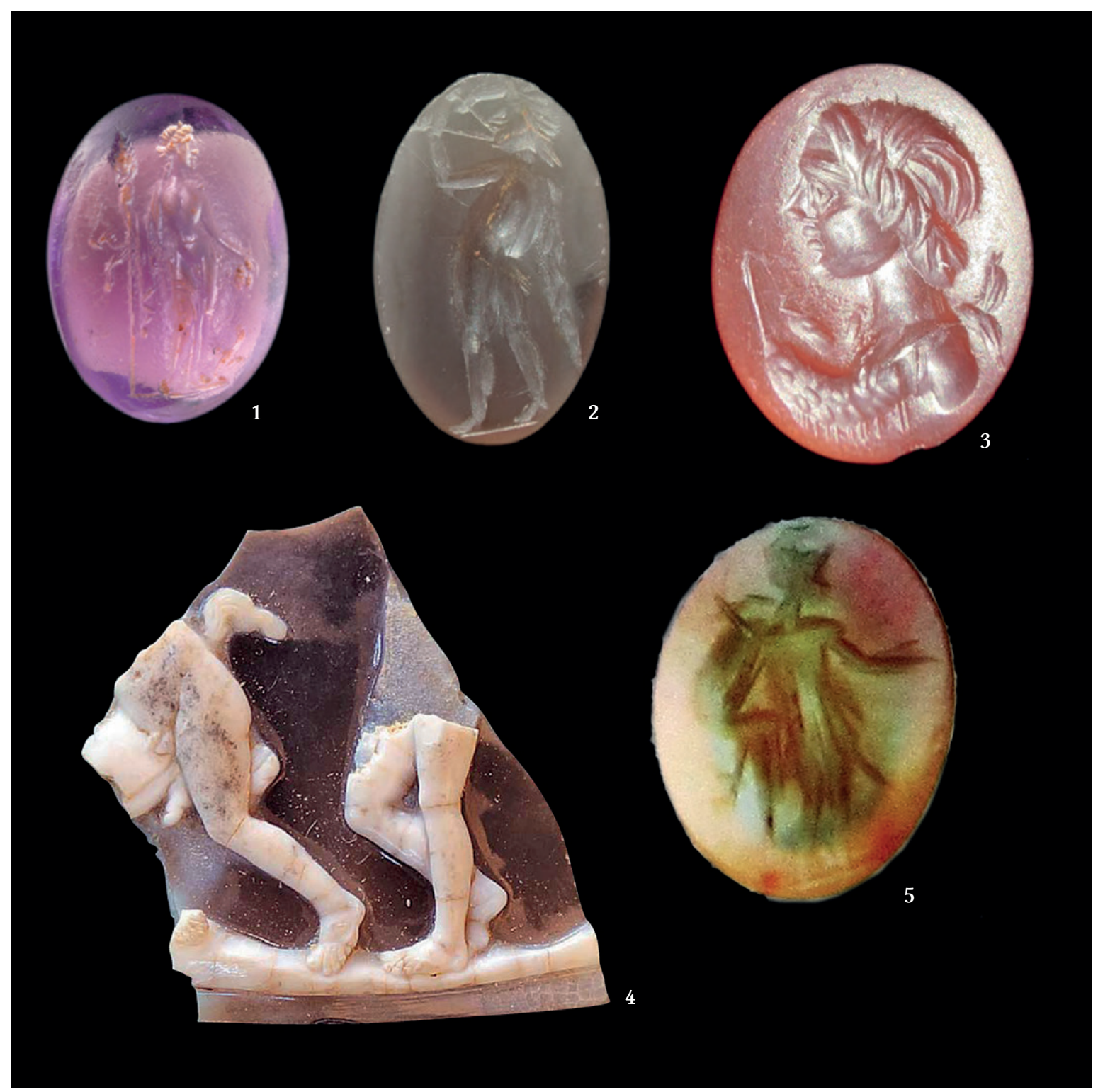

Fig. 2. Roman engraved gems from Southeast Asia (already re-examined). (All images are in individual size).

with ivy vines and leaves), in the other a kantharos (drinking cup). His animal, a panther, accompanies him, turning his head towards the god. Bacchus images were often represented on amethyst in order to protect their wearers from methe (drunkenness), as in Greek the name of the stone means "not drunken". ${ }^{25}$ The Tha Chana piece can presumably be dated to the $1^{\text {st }}$ century AD.

Khao Sam Kaeo (Chumphon Thailand) also yielded a Roman intaglio presumably dated to the mid$2^{\text {nd }}$-early $3^{\text {rd }}$ century AD (Fig. 2,5). ${ }^{26}$ Although this object is again lacking secure archaeological context, as B. Borell emphasizes, its provenance from the site is not doubted ${ }^{27}$ The gem is depicting a standing figure, probably Mars, dressed in a military costume with a crested helmet and spear. One arm is bent on his hip, a sword hangs down behind, the upper part carries a shield, and a paludamentum (short military cloak) is draped over the arm. The other hand is probably holding a patera (libation bowl).

26 Wright 2009, 57; Pongpanich 2013, 98; Borell et al. 2014, 102, Fig. 5a-b; Borell 2017c, 611-612.

27 Borell 2017c, 591. The same is true for the other Khao Sam Kaeo seals published in the same paper. 


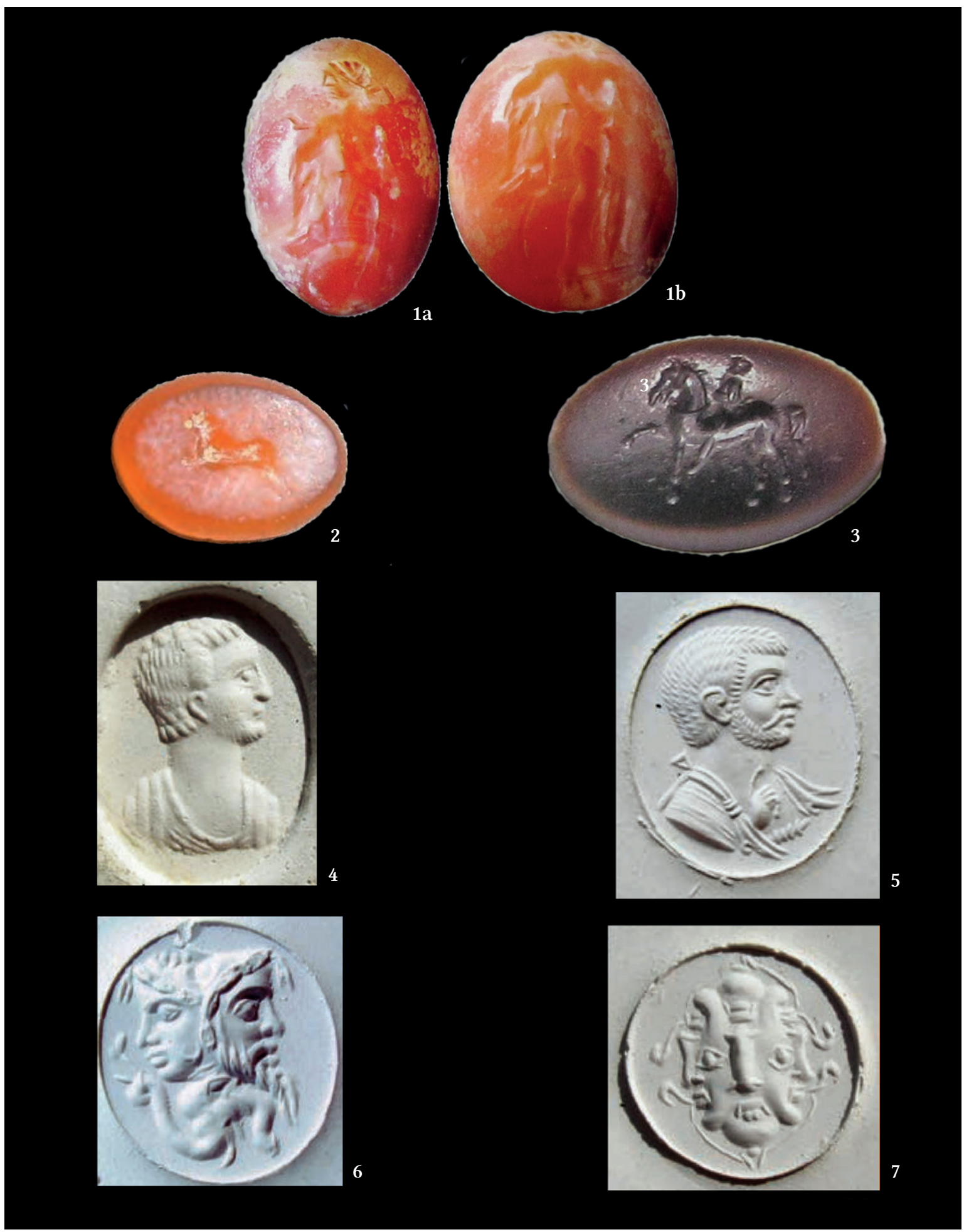

Fig. 3. Non-Roman engraved gems from Southeast Asia (already re-examined). (All images are in individual size).

Among the Southeast Asian sites yielding Roman (or Roman-believed) artefacts unquestionably Óc Eo (An Giang Province, Vietnam) is the most recognized. L. Malleret in his iconic work published several intaglios featuring western elements ${ }^{28}$, however a detailed re-examination of these

28 Regarding glyptics: MAlleret 1951, Pl. 47, Pl. 49; MAlleret 1962, 385, Pls 66-68; See also: LAPTEFF 2016, 300, Fig. 2. 
items is needed in order to recognize the objects of Mediterranean origin. ${ }^{29}$ In this manner, the red jasper intaglio depicting a chariot drawn by two mice, and with a cock as a charioteer ${ }^{30}$ can be $^{2}$ connected to the Roman Empire with relative certainty (Fig. 1,5). Gems with such humorous animal representations - which are often referred to as the 'reversed world' 31 - had amuletic character, and this particular object can be dated to the $2^{\text {nd }}$ century $\mathrm{AD}$. Another example of Roman glyptics is a translucent green glass intaglio with the motif of a wreath discovered in Đá Nổi (Kiên Giang province; Fig. 1,6). ${ }^{32}$ As S. Middleton noted, Aquileia has also yielded an identical glass intaglio, which may even be from the same mold..$^{33}$

Unfortunately, none of the intaglios published by Malleret came from properly documented excavation, and many were surface finds, thus share uncertain archaeological background. ${ }^{34}$

\section{Some non-Roman examples}

Among the regionally/continentally-made engraved gems, some of the artifacts feature high quantity and/or quality of western elements which makes their identification somewhat complicated. These had typically been connected to the Mediterranean world. Recent re-examination however, have shown that despite their great resemblance to Roman glyptics, they were in fact made outside of the Imperium.

In some cases, it is even possible to detect objects indicating adoption of (a set of) artistic elements, imaginary or visual solutions etc., derived from the classical world which were applied to make western-inspired objects through using local material and utilizing local techniques. Depending on the degree and quality (local technological and artistic abilities) of adoption, resulting objects might be very close to their western counterparts, thus differentiation might only be possible via careful iconographical and technological analysis. In this manner, adoption differs from adaptation, as acceptance characterizes the former, while translation and transformation play a greater role in the latter. ${ }^{35}$

Such example of adoption of western (in this case Roman) characteristics is the layered sardonyx intaglio depicting a walking horse and a rider, a notable stray find from Bang Kluai Nok (Fig. 3,3).36 The "fine and sensuous modelling of the horse's head and legs and the wavy movement in the rendering of the horse's tail are very much in the tradition of Roman gem-cutting and would suggest a date in the late first century BCE to the early first century CE.", however some peculiar features ("like the spiky mane and, most notably, the absence of a ground line") seem to point towards a more eastern place of origin, ${ }^{37}$ and presumably to a later date. Furthermore, it is interesting to note,

See e.g., Borell 2016. For re-examination of other Óc Eo discovered objects see: Borell 2008.

E.g., Ceedìs 1947, 197, Pl. D1; Malleret 1951, 195-196, Pl. 49,8; Malleret 1962, no. 1293, 299, Pl. 68; BORELL 2016, 109, 110, Fig. 8.

Gesztelyi 2005, 143; Gesztelyi 2005, 160, Cat. 33.1484.

E.g., Malleret 1951, 199, Pl. 47,3; Malleret 1962, No. 1314, 304, Pl. 72; 110, Fig 13,111; Middleton 2005 , 17.

Middleton 2005, 17; Sena Chiesa 1966, 401, No. 1415, Pl. 71.

Middleton 2005, 18; Problems of establishing stratigraphical context also mentioned by CEEDÈs 1947, 195.

See in detail: HoppáL et al. forthcoming.

E.g., Kangked 2009, 65, 88-89; Chaisuwan - NaiYawat 2009, 100; Wright 2009, 53; Chaisuwan 2011 , 89, 92; Noonsuk 2012, 38-38; Bellina et al. 2014, 83; Borell et al. 2014, 103, Fig. 7a-b; LApteff 2016, 301, 304, 310, Fig. 18;

From which Bactria was excluded by the authors see Borell et al. 2014, 103. 

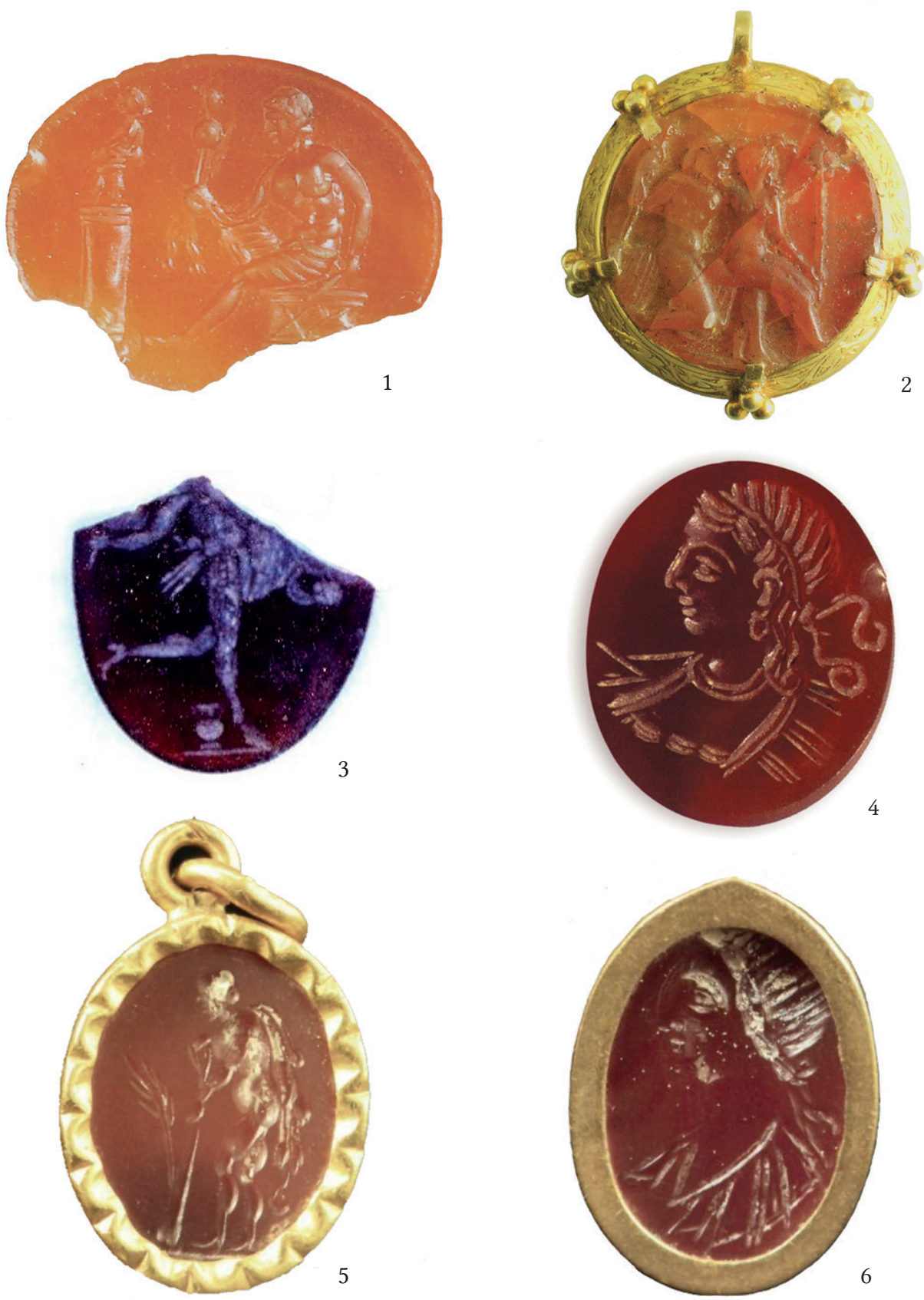

Fig. 4. Engraved gems integrating western elements to varying degrees from Southeast Asia (yet to be re-examined). (All images are in individual size).

that the same private collection is holding other engraved gems with the same motif and in a similar style. Such as a small, rounded intaglio with a horse and its male rider which was claimed to be discovered in Southern Thailand (Fig. 6,1). ${ }^{38}$ There is another example from Southern Thailand, an oval stone on which the horse is rather galloping than walking, but the overall posture of its rider is similar to what is depicted on the above two stones (Fig. 6,2) ${ }^{39} \mathrm{~A}$ third piece was also discovered in Southern Thailand, although it represents a slightly different scene, as the rider of the walking 

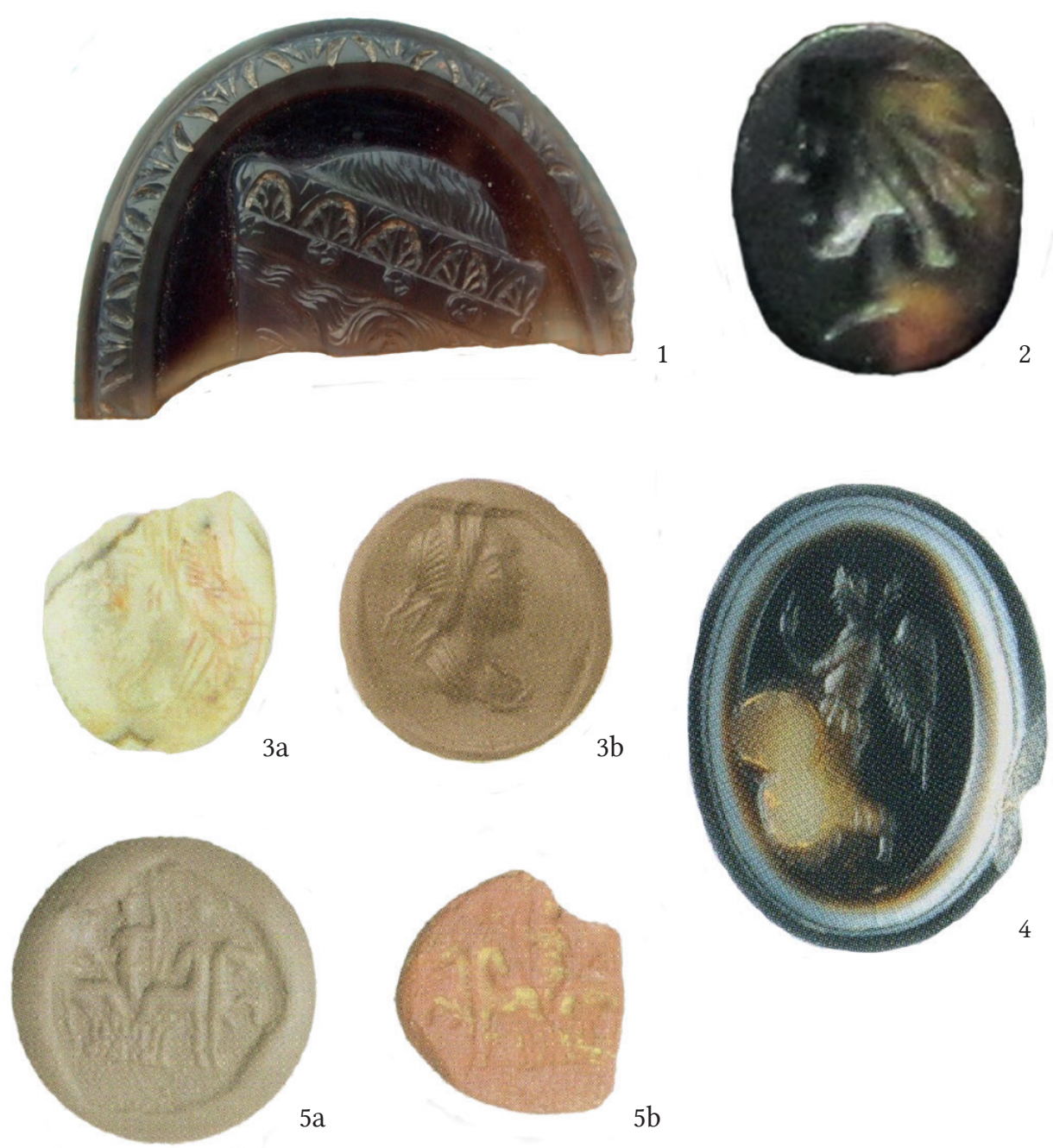

Fig. 5. Engraved gems integrating western elements to varying degrees from Southeast Asia (yet to be re-examined). (All images are in individual size).

horse wears a winged helmet, and the style also differs from the above examples (Fig. 6,5). ${ }^{40}$ Stones depicting individual horses - mostly in a standing position - can also be found. Such as an oval gem reportedly from Bang Kluai Nok on which the horse is standing next to a column (Fig. 6,4a-b). ${ }^{41} \mathrm{~A}$ cruder and a more ill-proportioned version of the same motif can be seen on a carnelian(?) stone from Southern Myanmar (Fig. 6,3). ${ }^{42}$ At the same time, all the above cited items require further analyses in order to have a better understanding on their possible production places. However, the general absence of a ground line supports a regional-continental (South Asian?) origin.

Another recently (re-)considered example of possible adoptions is an agate intaglio with a male figure acquired from its local owner in 2007, and reported to be found in Phu Khao Thong (Fig. $3,1 a-b) .^{43}$ The finely worked gemstone is depicting the standing youth Herakles, in one hand he is holding a club which rests on the ground, while his other arm is bent on the hip. A lion skin is

40 Lapteff 2016, 301, 304, 306, Fig. 10; Pongpanich 2019, 267.

41 Wright 2009, 54, Figs 1-2; PongPanich 2013, 171; LAPtefF 2016, 301, 304, 310, Fig. 18; PongPanich 2019, 250.

42 PongPanich 2019, 266.

43 E.g., Chaisuwan - Naiyawat 2009, 100; Kangked 2009, 52, 88-89; Wright 2009, 51; Noonsuk 2012, 37-38; Pongpanich 2013, 158; Lapteff 2016, 301, 304, 309, Fig. 17. 
draped over his forearm. Although the object is often seen as a Roman product, in fact its origin lays in the northern or northwestern region of South Asia, possibly in Gandhāra. Such locally produced objects with Herakles representations were derived from classical motifs, and from Hellenistic Herakles types that existed on coinage of Bactria and northern India. ${ }^{44}$

The possible production area of two, previously West-connected gems from Óc Eo might also be found in Gandhāra. One is a carnelian intaglio depicting a bust of a man with his hand raised in redegestus (a gesture of speech; Fig. 3,5). ${ }^{45}$ The fine modelling and the execution of the hair and the beard resembles to the $3^{\text {rd }}$ century AD Roman military portrays on engraved gems and coins, while some details, typically his facial features, are comparable to the Gandhāran gems. Similarly, in case of the other carnelian intaglio depicting a bust of a bearded man (Fig. 3,4) ${ }^{46}$ an origin outside of the Roman Empire might be hypothesized. ${ }^{47}$

The problem of accessing engraved gems held in Southeast Asian collections might also lead to erroneous identifications. Such as in case of the circular carnelian stone with engraved script in a rounded frame. Based on the photo of the object which was only available at the time, the script was seen as of Greek letters, thus the object was identified being an Early Christian/Byzantine item. However, the intaglio in fact features Pallava script, which suggests local (regional-continental) origin. ${ }^{48}$

Concurrently and despite the detailed analyses, the origin of some of the West-connected objects cannot be sufficiently revealed. This problem of identifying engraved gems depicting classical scenes and/or featuring classical characteristics can be illustrated by the small carnelian intaglio bearing a representation of a galloping animal from Phu Khao Thong (Fig. 3,2). The artefact is one of the few with secure context since it was excavated in $2006,{ }^{49}$ although its small size and schematic character does not allow a closer dating nor a specific identification regarding its origin..$^{50}$ Another example of problematic identifications is the carnelian intaglio with the combination of two human figures and an elephant head from Óc Eo (Fig. 3,6). ${ }^{51}$ The modelling is delicate and vivid; the human figures are depicted in profile, one is bearded, the other is shaved, and the animal is an Asian elephant. Although the motif can be found among the $1^{\text {st }}-2^{\text {nd }}$ century AD Roman glyptics, some peculiar details, as well as the representation of the elephant reflect to an Indian style, and have analogies in Begram and Gandhāra. L. Malleret also published one more intaglio depicting a combination of human faces ${ }^{52}$ in this case its non-Roman origin is now more apparent (Fig. 3,7). ${ }^{53}$

\section{Objects yet to be (re-)examined}

There are a number of engraved gems integrating (a set of) western elements to varying degrees which require (re-)evaluation. Several of these objects have been connected to the Roman Empire in former literature, however further analytical studies would be essential to recognize the objects of Mediterranean origin. So much the more as in many cases rather a regional-continental (South Asian) production place might be hypothesized.

BORELL 2017b.

Malleret 1951, 197, Pl. 49,5; MAlleret 1962, 295-296, Pl. 67, No. 1279.

Malleret 1951, 197, Pl. 49,6; Malleret 1962, 298, Pl. 67, No. 1278.

Re-examination of these Óc Eo found intaglios: Borell 2016, 109-111, Fig. 11, Fig. 12.

Comp.: BouzeK - Ondřejová 2009, 149-150, 154, Fig. 2,5, vs. LiuchaichāN 2019, 37.

KANGKED 2009, 88-89.

BORELl et al. 2014, 103.

Ceedès 1947, 197, Pl. D2; Malleret 1951, 196, Pl. 49,7; Malleret 1962, 296, Pl. 68, No. 1280.

Malleret 1951, 196, Pl. 49,9; Malleret 1962, 297, No. 1281, Pl. 68.

Borell 2016, 109, 110, Fig. 9, Fig. 10. 

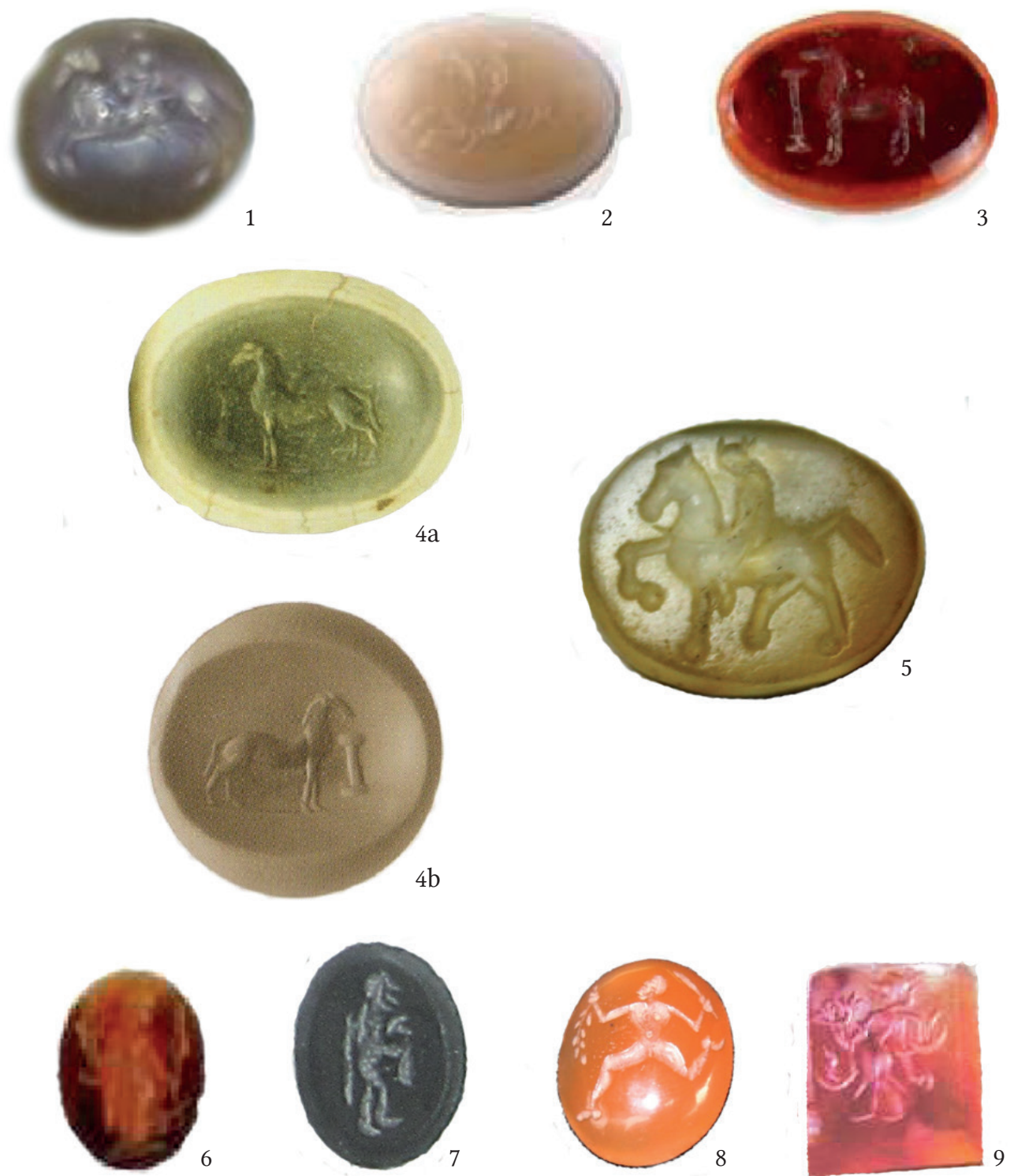

Fig. 6. Engraved gems integrating western elements to varying degrees from Southeast Asia (yet to be re-examined). (All images are in individual size).

The vast majority of these stones are again in private collections, out of which a remarkable amount was claimed to be discovered in Khlong Thom. A remarkable piece is a fragment depicting a satyr in a delicate style (Fig. 4,3). One-third of the original stone is missing. The male figure is standing one the tip of one leg, the other leg is raised and bent in the knee. In one hand a long object, possibly a thyrsos is held, and a skin of animal (panther?) is thrown over the other arm, which is also visible behind the back of the figure, as well as above the raised leg. A two handled vessel is placed on the ground line next to the leg. The analogies of the artefact can be found among $1^{\text {st }}$ century $\mathrm{BC}-1^{\text {st }}$ century AD century Roman glyptics, thus its Roman origin has been suggested, however only photographs of the object were available at that time.${ }^{54}$ Another object representing a classical scene is a fragment of a carnelian stone now held in the collection of the Suthi Ratana Foundation. The finely carved artefact shows a half-nude male figure, possibly Diomedes, who is seated on a decorated throne (Fig. 4,1). ${ }^{55}$ One of his legs is bent, the other is outstretched. In one hand he is holding the Palladium of Troy, and in front of him there is a 
column with a statue (possibly Athena/Minerva). The lower section of the stone is missing, but a dead guard may also be represented near his feet. The motif was popular in Roman glyptics, particularly in Augustean times when the image was filled with political meaning. ${ }^{56} \mathrm{On}$ another Khlong Thom-found carnelian cameo in the same private collection two human figures referred to as 'Aphrodite and Ares' are depicted (Fig. 4,2). ${ }^{57}$ The non-Roman origin of a third carnelian intaglio of woman or elsewhere Hellenistic king is more plausible (Fig. 4,4). Bust of the figure is delicately engraved, the hairstyle is finely rendered, and decorated by a diadem, while the face is more plastically depicted. Although its style is comparable with the $1^{\text {st }}$ century $\mathrm{AD}$ Roman glyptics ${ }^{58}$ but the overall appearance suggests a more eastern production place, ${ }^{59}$ and can be compared to another Khlong Thom-found carnelian intaglio bearing an image of a male bust (Fig. 4,6). ${ }^{60} \mathrm{Khlong}$ Thom also yielded a number of other engraved gems featuring western characteristics, although most of them certainly have non-Roman origin, such as the intaglio representing the standing Herakles holding a club (Fig. 4,5). ${ }^{61}$ Additional profile busts can also be found in the collection of the Suthi Ratana Foundation, out of which two remarkable pieces have been discovered in Tha Chana. One is a high-quality cameo fragment bearing a profile head with a diadem in a decorated frame (Fig. 5,1). ${ }^{62}$ The style of the headpiece might be comparable with Antonia minor's representations, while the delicate carving seems to suggest production of an imperial workshop, however further analyzes would be needed to confirm these assumptions. ${ }^{63}$ The other piece from Tha Chana is intact, but characterized by less ornamented features (Fig. 5,2). ${ }^{64}$ Bang Kluai Nok has also yielded one more gem bearing classical characteristics, namely an oval stone with a winged figure in profile (Fig. 5,4). ${ }^{65}$

Roman-interpreted items requiring further re-examination can also be found in Cambodian private collections. Such as the oval intaglio from Phum Snay (Banteay Meanchey Province) depicting a running(?) male figure who is holding a sword in one hand, and a branch in the other (Fig. 6,8). ${ }^{66}$ However, neither its carving nor its overall style can be considered as typical for Roman glyptics. Several other examples of engraved gems integrating western elements to varying degrees have been reported from Southeast Asia, ${ }^{67}$ although most are apparently not Roman.

\section{Examples of possible adaptations}

Regarding western style artefacts made of local material and techniques besides examples of adoption, artefacts indicating adaptations of western technical or artistic elements might also be expected among Southeast Asia found engraved gems. Such adaptations are characterized by translation and transformation in which the selective appropriation and re-contextualization of western

56 E.g., Forbes 1995, 26, Figs 16-17, with more examples.

57 Wright 2009, 47; Pongpanich 2013, 150; Lapteff 2016, 301, 304, 309, Fig. 16.

58 BouzeK - OndřEjová 2009, 149, Fig. 1,2, Fig. 2,2. Other references: Glover 1996, 65; Chaisuwan - NAIyaWat 2009, 95; Wright 2009, 49, Fig. 3; Noonsuk 2012, 50-51; PongPanich 2019, 250.

59 B. Borell personal communication (12.01. 2022).

60 LiUCHAichan 2019, 62.

61 B. Borell personal communication (12. 01. 2022). Also: Noonsuk 2012, 50, 53, Fig. 1,16.

62 Pongpanich 2013, 108; Lapteff 2016, 301, 304, 307, Fig. 11; Pongpanich 2019, 267.

63 Professor T. Gesztelyi personal communication (15. 07. 2021).

64 Wright 2009, 56, Fig. 4; Pongpanich 2013, 108; Lapteff 2016, 301, 304, 307, Fig. 12; Pongranich $2019,267$.

65 Pongpanich 2008, 35-36; Lapteff 2016, 301, 304, 310, Fig. 18; Pongpanich 2019, 250.

66 LAPTEFF 2016, 315, 316, Fig. 27.

67 E.g., Wright 2009, 47-57; Noonsuk 2012, 37-38, 50, 53; Pongpanich 2013, 171; Lapteff 2016, 301, 304, 310, Fig. 18; Pongpanich 2019, 250. A few intaglios from Myanmar could either be Roman or Sasanian. See e.g. Middleton 2005, 161. 
visual/technical solutions might also play a significant role. In these cases, western elements enrich the local visual culture, and some of these artefacts could even be understood in context of cultural globalization, thus indicating yet another level of interactions. ${ }^{68}$

At the same time, in case of the Southeast Asia discovered engraved gems featuring western characteristics, further technological comparative studies would be needed to identify such items. A possible example which might be worth of further examination is a carnelian intaglio from Lop Buri Province, bearing an image of a female figure holding a cornucopia, thus referred to as Fortuna in the literature (Fig. 6,9) ${ }^{69}$ The style clearly differs from the visual repertoire of the classical world; however, some elements might be interpreted as a kind of translation of certain western artistic solutions.

\section{'Social life' of gems}

As has already been stipulated, vast majority of the aforementioned examples of engraved gems are lacking secure archaeological context which makes further analysis regarding how these objects might have been received in local community(ies) somewhat difficult, however there is need to add a few thoughts and assumptions on the 'social life' of these items.

Among the re-examined gems, in case of 11 items can Roman origin be hypothesized, while Indian-inspired and particularly Gandhāra-originated items are also present, such as the carnelian stones with male bust from Óc Eo, or the agate intaglio depicting Herakles from Phu Khao Thong. In case of other, yet to be analyzed engraved gems featuring highly skilled techniques and delicate style, hypothesizing South Asian origin might be probable, although other production places could also be reasonable. Moreover, even the local production through highly skilled Indian technologies cannot be entirely ruled out, since, as an illustration, production of Indian-inspired high-quality stone ornaments possibly by South Asian artisans or local artisans trained by South Asians has been demonstrated at Khao Sam Kaeo ${ }^{70}$ which hypothesizes that technological and artistic abilities for making high-quality engraved gems featuring western elements might have also been available locally.

Taking into account the general dating problems regarding engraved gems, in case of the re-examined objects only tentative production dates could be suggested, which might differ from their actual date of arrival to Southeast Asia. According to the re-evaluations, six of the Roman and possibly four of the non-Roman engraved gems presented above can be dated to the $1^{\text {st }}$ century $\mathrm{BC}-1^{\text {st }} / 2^{\text {nd }}$ century $\mathrm{AD}$, while three of the Roman and two of the non-Roman artefacts to the (post) $2^{\text {nd }}-3^{\text {rd }}$ century AD. There are a few cases - typically from China - when the secure context of objects of Mediterranean origin suggests relatively short time spans between the production and burial of the item. ${ }^{71}$ This might have been the situation in case of the $1^{\text {st }}$ century $\mathrm{BC}-1^{\text {st }} / 2^{\text {nd }}$ century AD dated Roman glyptics discovered in Thailand as those fit into the most active period of the sites where they were claimed to be found (See Appendix). Moreover, these early dates correlate with the intensification of interactions via the Indian Ocean connecting larger parts of the Indian subcontinent to the Mediterranean, but also with the end of the first phase of Indian-Southeast Asian contacts, during which a great variety of items testify already regular exchange. While the $2^{\text {nd }}-3^{\text {rd }}$

68 For examples see: Hoppál et al. forthcoming.

69 BHUMADHON 2019, 184.

70 BELLINA 2014, 366-367.

71 Such as in case of the often-cited marbled ribbed bowl excavated from a 67 AD dated tomb in Ganquan. See: NANJing BowUyuan 1981. For more examples of short and longer time spans see: Hoppál et al. forthcoming. 
century dated engraved gems refer to the period of the mass production of Roman engraved gems, and also correlate with the period when Roman engagement in Indian Ocean exchange appeared on a lesser scale. These dates can also be related to the second phase of interactions between India and Southeast Asia, when inter- and intra-regional exchange intensified and objects of a lesser diversity but greater quantity can be found. ${ }^{72}$

Regarding raw materials, carnelian, a variety of the silica mineral chalcedony, was used the most often for the presented engraved gems - both in case of the Roman and the non-identified pieces. Carnelian was among the most popular stones used for gem carving in the Roman Empire (which is particularly visible in Roman provincial collections, such as in Portugal or Hungary ${ }^{73}$ ), but beads and pendants made of carnelian can also be often found in Southeast Asia, particularly in the central and southern parts of Thailand and Vietnam. ${ }^{74}$ The isotropic physical character makes carnelian easy for engraving, ${ }^{75}$ and its red color also made the stone popular in the Roman Empire for amuletic gems ${ }^{76}$ However, origin of carnelian used in Roman glyptics - i.e., whether local or imported is still uncertain. ${ }^{77}$ Besides agate, carnelian was also frequent among Southeast Asia-discovered ornaments with a style that includes religious or auspicious symbols. ${ }^{78}$ Moreover, in Southeast Asia carnelian and agate can be considered as ideal status marker as not only the style of ornaments is a social signal, but their manufacturing technologies as well, therefore provide clues on the exchanges in which they were involved..$^{79}$ The mineral originates in the Indian subcontinent, and despite the fact that other sources such as Indonesia and central Thailand also existed ${ }^{80}$ a recent geochemical research regarding Thailand and Cambodia discovered beads suggests that South Asia secured its significant role in providing the raw material for carnelian and agate artefacts as half of the analyzed 79 samples originated from the Deccan Traps in India. ${ }^{81}$

The fact that the largest published collection of engraved gems featuring western elements had been reportedly collected from one single area i.e., southern Thailand (and partly southern Myanmar) justifies to add some further observations regarding the possible perceptions of these objects in local communities.

Taking into account the difficulties of differentiation between Roman engraved gems and non-Roman stones featuring western elements, it seems to be rightful to assume that local communities were not able to recognize the various production places, thus for Southeast Asian consumers intaglios and cameos of Mediterranean origin were possibly not appreciated because of their 'Romanness' i.e., coming from a distant and exotic land, but rather because of their technical and artistic values, and excellent quality.

72 For periodization of Roman-Indian Ocean exchange see e.g., Cовв 2018, 287. For phases of Indian-Southeast Asian contacts: BeLlinA - GLOVER 2004, 72-80.

73 See Cravinho 2017; Gesztelyi 2005, 9.

74 See e.g., Hung - Bellwood 2010, 238-239; Bellina - Glover 2004, 73; Borell 2017a, 26. All with further bibliography. At Khao Sam Kaeo, among siliceous type of raw materials traditional South Asian good-quality carnelian used in order to make stone ornaments displaying different technological and stylistic characteristics appears the most often. BELLINA 2014, 352-355, 358.

75 For a general overview regarding the popularity of deep red gemstones in the Roman Empire see e.g., AdAms 2011, 12.

76 MASTROCINQUe 2011, 62.

77 The stone might have arrived from Epirus, Egypt, Arabia, or India. See along with the ancient nomenclature: THORESEN 2017, 178.

78 E.g., in Khao Sam Kaeo, see Bellina 2014, 358.

79 BELLINA 2003, 286-287.

80 Theunissen et al. 2000, 92; Bellina 2003, 289.

81 Carter - Dussubieux 2013. 
Studying the motifs carved into the gems, the most glaring observation is that items with human representations are the most frequent, more than $80 \%$ of the entire assemblage of western-like items discovered in southern Thailand (and Myanmar), out of which (Roman) religious beliefs and sacro-idyllic scenes appear to be the most common subjects. Among human depictions, bust portraits are present in a remarkable number (27\%), while animals are represented on only $15 \%$ of the artefacts. At the same time, it would be important to examine all objects from the area, including Indian and Indian-inspired locally made items for the sake of comparison. It can also be safely argued that individual choices of the founders (looters) and specific demand from the buyers' side will also have manipulated the proportion of gems selected for these private collections. Although each Roman province had its own peculiar characteristics - particularly Alexandria, ${ }^{82}$ the potential production place of many Roman objects found in the East ${ }^{83}-$, it is interesting to note, that in general, similar distribution of representations can be seen in case of Roman glyptics. ${ }^{84}$ This might suggest that these Southeast Asia-found intaglios and cameos were not preselected specifically for the East by the Roman side. The fact that among the non-Roman gems proportion of popular motifs is very similar to what can be seen on the Imperium-arrived artefacts seems to suggest that the local/ regional (South Asian) producers followed the same trend, probably because at least partly based their works on the available Roman originals, particularly in case of the examples of adoptions. In the meantime, a detailed comparison between South Asia and Southeast Asia discovered Roman engraved gems might disprove the above hypotheses.

Considering the number of western and western-like engraved gems found in southern Thailand (and Myanmar), it seems plausible that these objects might have had a meaning for the consumer beyond their aesthetic recognition. Theorizing an amuletic character of good fortune, prosperity and longevity attached to these intaglios and cameos might be one of the reasonable possibilities. Within and central to this aspect, Southeast Asia discovered ornaments copying Roman coin designs might be comparable to the appreciation of engraved gems - particularly to the profile head representations. The practice of wearing such coin adaptations was well-known in India and might have been imported from the southern regions of the Subcontinent to Southeast Asia. Important part of the decoration was the obverse with profile head - as both the one-sided pendants and the location of the suspension loop fitting into the decoration design suggest. Both in India and Southeast Asia, wearing genuine Roman coins and copies of Roman coin designs had apotropaic and auspicious aspects, and were symbols of wealth and status, particularly in case of gold ornaments, and the amuletic and protective character might also explain the existence of crudeness of the representations. ${ }^{85}$

Moreover, adaptations of the iconography, symbolism and function of certain Roman artefacts into the local cultural conceptions might also be suggested as another aspect of local acceptance of these gems. In South Asia, example of such cultural adaptation of Roman objects has already been demonstrated, namely the alabaster object presumably representing Eros in a half egg from Junnar, which could have been appreciated for its symbolism within an Indian context. ${ }^{86}$ This might indicate cultural/religious syncretism and transculturalism, however finding more of such evidences among objects of Mediterranean origin discovered in Asia would be needed in order to fathom the presence of these West-arrived objects beyond the terms of direct/indirect exchange. Incorporation of specific images into the local symbolism would explain the repetition of certain western-style 1963.

83 For examples see: HoppÁl et al. forthcoming

84 See e.g., Gesztelyi 2005, 143; Cravinho 2017, 3.

85 BrancACCIO 2005, 401-402; BorEll 2014, 29-30. For a summary see: HoppÁl et al. forthcoming

86 CoBB - Mitchell 2019. 
motifs in different style and quality, such as the cock, the horse and its rider, or the standing and galloping horses. The latter might be comparable with the few stone horse amulets of South Asian imagery found in the Indian subcontinent and in southern Thailand (namely at Khao Sam Kaeo). ${ }^{87}$

In order to produce a more solid evidence-base, more comparative studies would be needed to uncover other aspects of possible perceptions regarding western-connected engraved gems. It would also be crucial to study whether those were simply trade-connected items or a special interest among local communities existed towards these intaglios and cameos as is the case for the China-discovered glass vessels of Roman origin, where a certain degree of appreciation refilled with specific cultural features can be visualized towards transparent (and translucent) glass vessels. ${ }^{88}$ However, the very first step should be to conduct further technological studies, such as investigating engraving techniques and treatments of gemstones, as well as comparing eastern and western glyptic manufacturing methods,${ }^{89}$ in order to build a comparative corpus of materials.

\section{Conclusion}

In case of engraved gems presented in the paper two subcategories focusing on style and technique can be seen in particular. These are the objects of Mediterranean origin arriving via indirect contacts, and western style artefacts made of mostly but not exclusively South Asian raw material and techniques. It is important to note however that none of the above categories imply sustained or close interactions between the Roman Empire and Southeast Asia. While artefacts of Mediterranean origin are well-recognized in the literature, their implications regarding the nature of interactions are often overestimated, typically in case of objects discovered beyond the Indian subcontinent, as the mere presence of them per se is not sufficient to indicate strong cultural connectedness or close transfer. In case of western style artefacts made of local material and techniques, recognition and even comprehension of certain western visual solutions (by the manufacturing community) can be seen, which therefore suggest some degree of integration into the local cultural conceptions. In this regard, this subcategory would indicate a closer cultural connectedness. However, most of the non-Roman engraved gems examined in the paper can in all likelihood be connected to a regional-continental (Indian subcontinent) not a Southeast Asian production place, which makes these objects similarly 'foreign' for the local cultural conceptions as the Roman originals are. Notwithstanding the abovementioned and as has been suggested, some of these South Asia and Imperium made engraved gems might have been appreciated for their symbolism within a local Southeast Asian context indicating some degree of cultural/religious syncretism and transculturalism.

The fact that Southeast Asian private collections are holding several dozen potentially Roman engraved gems not only illustrates the problems of looting, not only illustrates the problems of looting and the local efforts for securing these objects, but also shows the scale of interest. Further research is therefore required to systematically analyze all these objects while balancing between academia and encouragement for further looting. At the same time, the several ongoing scientific fieldworks such as the projects carried out by the French-Thai and French-Malay collaborations are providing further possibilities to find objects in secure context ${ }^{90}$ thus allowing possibilities for more complex and solid interpretations.

87 For examples see: BELlina 2014, 376.

88 For this see: Hoppál 2016.

89 As Rosenfeld et al. $(2003,238)$ suggested in case of Roman glyptics.

90 Such as glass finds of Mediterranean origin excavated in Peninsular Myanmar: Dussubieux - BeLlinA 2017a; Dussubieux et al. 2020. 


\section{Acknowledgement}

The author is deeply grateful to Dr. Bérénice Bellina for her valuable advices, and to Dr. Dagmar Muchnová for providing the original illustrations of the late Dr. Bouzek and Dr. Ondřejová's papers. The author also like to thank Dr. Brigitte Borell and Dr. Tamás Gesztelyi for their invaluable help in analyzing and interpreting the materials, and Dr. Strobe Driver for reviewing the paper from another academic perspective.

\section{Appendix}

\section{Sites Mentioned in the text}

Phu Khao Thong (Peninsular Thailand, Ranong province)

A port-entrepôt and specialized industrial site with ceremonial/political feature, part of cluster sites (including the neighbouring settlement Bang Kluai Nok) representing large trading communities on the Western coast of the Kra Isthmus. Extensive looting limits precise dating, but the settlement sequence possibly started as early as the early $3^{\text {rd }} / 2^{\text {nd }}$ century $\mathrm{BC}$, giving a remarkable number of materials dated to the late $1^{\text {st }}$ century $\mathrm{BC}$, and may have been extended until the $2^{\text {nd }}$ or $3^{\text {rd }}$ century $\mathrm{AD} .^{91}$

Bang Kluai Nok (Peninsular Thailand, Ranong province)

A significant coastal trading station and main settlement of the closely related Phu Khao Thong. Again, extensive looting limits precise dating, but the settlement sequence seems to correlate with Phu Khao Thong. ${ }^{92}$

Tha Chana (Peninsular Thailand, Surat Thani province)

A port-entrepôt site which - like Phu Khao Thong - also yielded large amounts of remains of craft industries whose products were distributed locally as well as regionally as far as the Philippines. It has been looted possibly as early as 1977 . Its early phase possibly started during the $1^{\text {st }}$ century BC - early centuries AD, but it had a later, Sriwwijaya era-connected period (between $500-1000 \mathrm{AD}$ ) as well. Therefore, it is assumed that Phu Khao Thong (and Bang Kluai Nok) had developed earlier than Tha Chana. ${ }^{93}$

Khao Sam Kaeo (Peninsular Thailand, Chumphon province)

The site emerged as the earliest cosmopolitan incipient city-state acting as the "inter-regional" market place for a confederation that included Khao Sek and other feeding points and relay stations. The site has been severely looted but benefited from excavations carried out by the French-Thai collaborative archaeological mission. Research has demonstrated its cosmopolitan configuration hosting multiple resident communities (South Asian, Southeast Asian and East Asian), and large amount of craft industries. The chronological sequence of the site is well-based by radiocarbon dates and chrono-typological methods. The main occupation time is agreed to span from the end $-5^{\text {th }}$ to the $2^{\text {nd }}$ centuries $\mathrm{BC}$, although the site may have been used during the early centuries AD, but less actively. ${ }^{94}$

Khlong Thom (Peninsular Thailand, Krabi province) also known as Khuan Lukpad ("Bead Mound").

The site hosted several craft activities and local coinage probably associated to a trading polity but whose excavations were limited by the extensive looting of the place since the 70's. It possibly had already been occupied as early as the $1^{\text {st }} \mathrm{BC}$, but its main activity as an entrepôt can be dated to the first centuries $\mathrm{AD}$, and it also flourished during later periods, as the presence of Middle Eastern ceramics of the $9^{\text {th }}$ century also suggests. ${ }^{95}$

91 Chaisuwan 2011, 86-87; Pongpanich 2013; Bellina et al. 2014, 84; Borell et al. 2014, 100; Bellina 2017a, 634-635.

92 BELLINA 2017a, 636.

93 E.g., Srisuchat et al. 1987; Noonsuk 2012; Pongpanich 2013; Borell et al. 2014. with further bibliographies.

94 E.g., Bellina 2014; Bellina et al. 2014; Bellina 2017b. All with further bibliographies.

95 Veraprasert 1987; VAllibhotama 1988; Bronson 1990; Veraprasert 1992; Glover 1996a, 374-375; $\triangleright$ 


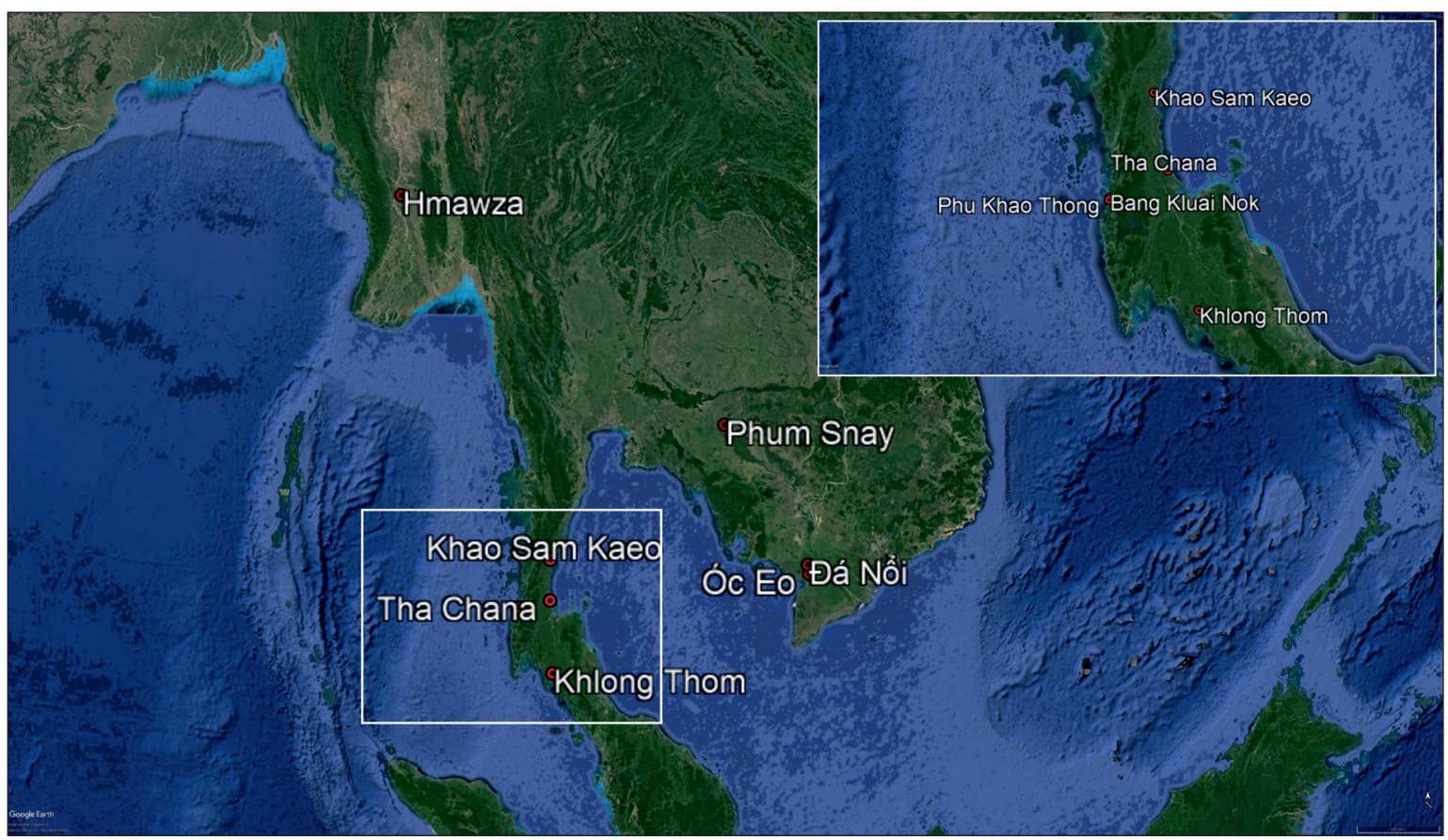

Fig. 7. General map of sites mentioned in the text with map of sites on the Kra Isthmus.

Srikshetra/Hmawza (Pyay District, Bago Region, Myanmar)

An iconic Pyu urban settlement, regional centre and port-entrepôt with concentration of monuments, statuaries and inscriptions. The site hosted a complexity of irrigation networks and brick fortifications, several craft industries, along with a large number of artefacts attesting a rich visual culture. The city was mentioned by Buddhist pilgrims Xuanzhang 玄牀 and Yijing 義淨 in the $7^{\text {th }}$ century. Archaeological surveys started as early as the 1900 s and continued up to present. Its early phase spans from the $2^{\text {nd }}$ century $\mathrm{BC}$ to the $4^{\text {th }}$ century $\mathrm{AD}$, and its Pyu-Buddhist period can be dated to the $4^{\text {th }}$ to $6^{\text {th }}$ centuries, the Buddhist Culture period to the $6^{\text {th }}$ to $9^{\text {th }}$ centuries. ${ }^{96}$

Óc Eo (An Giang Province, Vietnam)

A settlement complex known to be a significant port-entrepôt and urban area hosting several craft industries. The site is one of the important regional centres in the Mekong Delta which is connected by canals and rivers to the South China Sea enabling regional interactions and trade. The first detailed research had been carried out by L. Malleret, and has been continued by local and international projects. The early phase spans between the $2^{\text {nd }}$ century $B C$ and early $7^{\text {th }}$ century $A D$, while the later phase can be dated between the mid- $7^{\text {th }}$ century and $12^{\text {th }}$ century AD. The site is related to the Funan kingdom of Chinese records existed from the $1^{\text {st }}$ to the $6^{\text {th }}$ centuries AD. ${ }^{97}$

Đá Nổi (Kiên Giang province)

Another significant site of the Óc Eo culture located in the Mekong Delta at the intersection of several ancient canals. It was explored by Malleret and investigated by Vietnamese scholars. Like Óc Eo, brickcum-stone monuments were found at the site with strong Indian influence as attested by their architectural style and decoration, and the contents of the deposits in the temple foundations. ${ }^{98}$

$\triangleright \quad$ Srisuchat 1998, 103, 104, 107-110; Bellina 1998; Glover - Bellina 2001, 199; JACQ-Hergoualc'H 2002; 84-89; Manguin 2004, 285-286; Chaisuwan - NAiYawat 2009; 95-96, 103; PongPanich 2013; 138-153; ChaisuWAN 2011; 84-86; Borell 2019.

96 E.g., Aung Thaw 1978; Stargardt 1990; Moore 2009; Thein Lwin et al. 2014; Miksic - Geok Yian GoH 2016;

97 E.g., Malleret 1959-63; HÀ 1986; Bourdonneau 2003, 266-269, 270; MAnguin 2009, 110; BourdonNEAU 2010, 134-136, Pl. 7; LÊ 2015; ĐặNG - Võ 2017, with further bibliographies.

98 E.g., MALLERET 1959, 126-131; LÊ 2015; LÊ 2018 
Phum Snay (Banteay Meanchey Province, Cambodia)

An ancient necropolis in Northwest Cambodia, appr. $80 \mathrm{~km}$ from the temple ruins of Angkor, which was discovered in 2000 during road constructions. Despite of the excavations carried out by international projects; illegal looting endangered the burials. The rich grave goods included potteries, bronze, gold, carnelian and glass beads, Óc Eo type earrings, etc., however prestigious objects were only present in a lesser scale. The use of the cemetery might have started as early as the $5^{\text {th }}$ century $\mathrm{BC}$, but vast majority of the finds can be dated to the early centuries AD. ${ }^{99}$

\begin{tabular}{|c|c|c|c|c|c|c|c|c|}
\hline Category & Objects & Status & Provenance & Origin & $\begin{array}{c}\text { Hypothetical } \\
\text { dates }\end{array}$ & Material & $\begin{array}{l}\text { Illustra- } \\
\text { tion }\end{array}$ & Photocredit \\
\hline \multirow{12}{*}{ 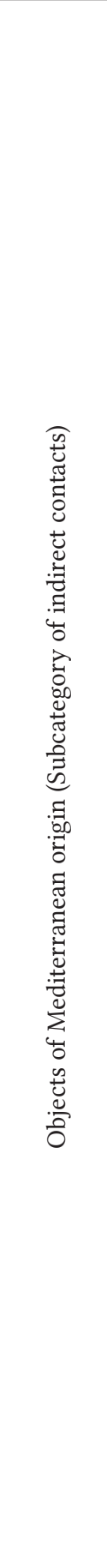 } & $\begin{array}{l}\text { Fortuna } \\
\text { intaglio }\end{array}$ & \multirow{12}{*}{ 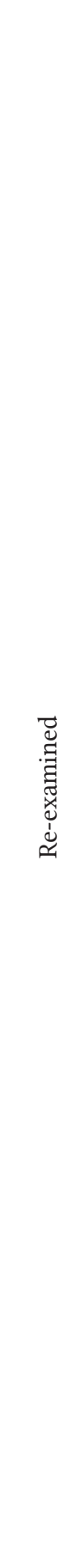 } & $\begin{array}{l}\text { Khlong } \\
\text { Thom (Krabi, } \\
\text { Thailand) }\end{array}$ & $\begin{array}{l}\text { Roman } \\
\text { Empire }\end{array}$ & $\begin{array}{l}\text { late } 1^{\text {st }} \text { to } 2^{\text {nd }} \\
\text { century AD }\end{array}$ & carnelian & Fig. 1,3 & $\begin{array}{l}\text { After BouZEK } \\
\text { - ONDǨEJOVÁ } \\
\text { 2010, 8, Fig. } 1\end{array}$ \\
\hline & $\begin{array}{l}\text { fighting } \\
\text { cocks } \\
\text { intaglio }\end{array}$ & & $\begin{array}{l}\text { Khlong } \\
\text { Thom (Krabi, } \\
\text { Thailand) }\end{array}$ & $\begin{array}{l}\text { Roman } \\
\text { Empire }\end{array}$ & $\begin{array}{l}\text { late } 1^{\text {st }} \text { to } 2^{\text {nd }} \\
\text { century AD }\end{array}$ & carnelian & Fig. 1,1 & $\begin{array}{l}\text { After BouzEK } \\
\text { - ONDŘEJOVÁ } \\
\text { 2010, 9, Fig. } 2\end{array}$ \\
\hline & $\begin{array}{l}\text { young } \\
\text { satyr } \\
\text { intaglio }\end{array}$ & & $\begin{array}{l}\text { Khlong } \\
\text { Thom (Krabi, } \\
\text { Thailand) }\end{array}$ & $\begin{array}{l}\text { Roman } \\
\text { Empire }\end{array}$ & $\begin{array}{l}\text { mid- } 2^{\text {nd }}-\text { early } \\
3^{\text {rd }} \text { century AD }\end{array}$ & carnelian & Fig. 1,2 & $\begin{array}{l}\text { After BouzeK } \\
\text { - ONDǨEJOvÁ } \\
\text { 2010, 10, Fig. } 3\end{array}$ \\
\hline & $\begin{array}{l}\text { bucolic } \\
\text { scene } \\
\text { intaglio }\end{array}$ & & $\begin{array}{l}\text { Khlong } \\
\text { Thom (Krabi, } \\
\text { Thailand) }\end{array}$ & $\begin{array}{l}\text { Roman } \\
\text { Empire }\end{array}$ & $\begin{array}{l}\text { post- } 1^{\text {st }} \text { century } \\
A D\end{array}$ & glass & $\begin{array}{l}\text { Fig. } \\
1,4 a-b\end{array}$ & $\begin{array}{l}\text { After BORELL } \\
\text { et al. 2014, 104, } \\
\text { Fig. } 8 \mathrm{a}-\mathrm{b}\end{array}$ \\
\hline & $\begin{array}{l}\text { satyr } \\
\text { playing a } \\
\text { double flute } \\
\text { intaglio }\end{array}$ & & $\begin{array}{l}\text { Phu Khao } \\
\text { Thong } \\
\text { (Ranong, } \\
\text { Thailand) }\end{array}$ & $\begin{array}{l}\text { Roman } \\
\text { Empire }\end{array}$ & $\begin{array}{l}\text { late } 1^{\text {st }} \text { century } \\
\mathrm{BC} \text { and } 1^{\text {st }} \text { cen- } \\
\text { tury } \mathrm{AD}\end{array}$ & agate & Fig. 2,2 & $\begin{array}{l}\text { After BoRELL } \\
\text { 2015, 51, Fig. } 10\end{array}$ \\
\hline & $\begin{array}{l}\text { young } \\
\text { satyr bust } \\
\text { intaglio }\end{array}$ & & $\begin{array}{l}\text { Bang } \\
\text { Kluai Nok } \\
\text { (Ranong, } \\
\text { Thailand) }\end{array}$ & $\begin{array}{l}\text { Roman } \\
\text { Empire }\end{array}$ & $\begin{array}{l}\text { late } 1^{\text {st }} \text { century } \\
\mathrm{BC} \text { and } 1^{\text {st }} \text { cen- } \\
\text { tury } \mathrm{AD}\end{array}$ & carnelian & Fig. 2,3 & $\begin{array}{l}\text { After BORELL } \\
\text { 2015, 51, Fig. } 10\end{array}$ \\
\hline & $\begin{array}{l}\text { two figures } \\
\text { cameo } \\
\text { fragment }\end{array}$ & & $\begin{array}{l}\text { Bang Kluai } \\
\text { Nok (Ranong } \\
\text { Thailand) }\end{array}$ & $\begin{array}{l}\text { Roman } \\
\text { Empire }\end{array}$ & $\begin{array}{l}\text { late } 1^{\text {st }} \text { century } \\
\mathrm{BC} \text { and } 1^{\text {st }} \text { cen- } \\
\text { tury } \mathrm{AD}\end{array}$ & sardonyx & Fig. 2,4 & $\begin{array}{l}\text { After Borell } \\
\text { et al. } 2014 \text {, } \\
\text { 103-104, Fig. } 1\end{array}$ \\
\hline & $\begin{array}{l}\text { Dionysos/ } \\
\text { Bacchus } \\
\text { intaglio }\end{array}$ & & $\begin{array}{l}\text { Tha Chana } \\
\text { (Surat Thani, } \\
\text { Thailand) }\end{array}$ & $\begin{array}{l}\text { Roman } \\
\text { Empire }\end{array}$ & $1^{\text {st }}$ century $\mathrm{AD}$ & amethyst & Fig. 2,1 & $\begin{array}{l}\text { After BoRELL } \\
\text { 2015, 51, Fig. } 10\end{array}$ \\
\hline & $\begin{array}{l}\text { Mars } \\
\text { intaglio }\end{array}$ & & $\begin{array}{l}\text { Khao } \\
\text { Sam Kaeo } \\
\text { (Chumphon } \\
\text { Thailand) }\end{array}$ & $\begin{array}{l}\text { Roman } \\
\text { Empire }\end{array}$ & $\begin{array}{l}\text { mid- } 2^{\text {nd }}-\text { early } \\
3^{\text {rd }} \text { century } A D\end{array}$ & carnelian & Fig. 2,5 & $\begin{array}{l}\text { Provided by } \\
\text { Bérénice Bellina }\end{array}$ \\
\hline & $\begin{array}{l}\text { 'reversed } \\
\text { world' } \\
\text { intaglio }\end{array}$ & & $\begin{array}{l}\text { Óc Eo } \\
\text { (An Giang } \\
\text { Province, } \\
\text { Vietnam) }\end{array}$ & $\begin{array}{l}\text { Roman } \\
\text { Empire }\end{array}$ & $\begin{array}{l}\text { the } 2^{\text {nd }} \text { century } \\
\mathrm{AD}\end{array}$ & jasper & Fig. 1,5 & $\begin{array}{l}\text { After BORELL } \\
\text { 2016, 110, Fig. } 8\end{array}$ \\
\hline & $\begin{array}{l}\text { wreath } \\
\text { intaglio }\end{array}$ & & $\begin{array}{l}\text { Đá Nổi } \\
\text { (Kiên Giang } \\
\text { Province, } \\
\text { Vietnam) }\end{array}$ & $\begin{array}{l}\text { Roman } \\
\text { Empire }\end{array}$ & $?$ & glass & Fig. 1,6 & $\begin{array}{l}\text { After BORELL } \\
\text { 2016, 111, Fig. } 13\end{array}$ \\
\hline & $\begin{array}{l}\text { walking } \\
\text { horse } \\
\text { and rider } \\
\text { intaglio }\end{array}$ & & $\begin{array}{l}\text { Bang } \\
\text { Kluai Nok } \\
\text { (Ranong, } \\
\text { Thailand) }\end{array}$ & $\begin{array}{l}\text { Eastern } \\
\text { origin? }\end{array}$ & $\begin{array}{l}\text { late } 1^{\text {st }} \text { century } \\
\text { BC - early } 1^{\text {st }} \\
\text { century AD? Or } \\
\text { later? }\end{array}$ & sardonyx & Fig. 3,3 & $\begin{array}{l}\text { After BORELL } \\
\text { et al. 2014, 103, } \\
\text { Fig. } 7\end{array}$ \\
\hline
\end{tabular}


Roman engraved gems from Southeast Asia

\begin{tabular}{|c|c|c|c|c|c|c|c|c|}
\hline Category & Objects & Status & Provenance & Origin & $\begin{array}{c}\text { Hypothetical } \\
\text { dates }\end{array}$ & Material & $\begin{array}{l}\text { Illustra- } \\
\text { tion }\end{array}$ & Photocredit \\
\hline \multirow{6}{*}{ 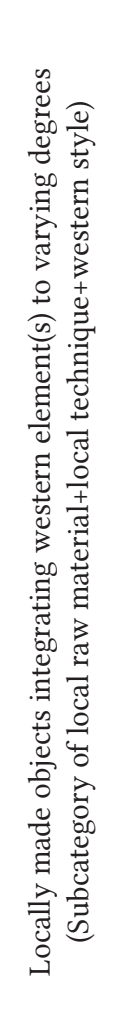 } & $\begin{array}{l}\text { Herakles } \\
\text { intaglio }\end{array}$ & \multirow{6}{*}{ 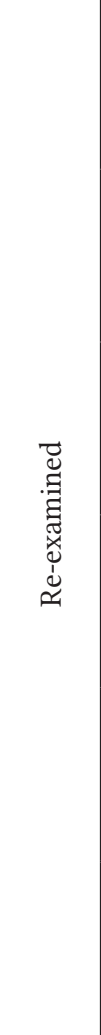 } & $\begin{array}{l}\text { Phu Khao } \\
\text { Thong } \\
\text { (Ranong, } \\
\text { Thailand) }\end{array}$ & $\begin{array}{l}\text { Gand- } \\
\text { hāra? }\end{array}$ & $1^{\text {st }}$ century $\mathrm{AD}$ & agate & $\begin{array}{l}\text { Fig. } \\
3,1 a-b\end{array}$ & $\begin{array}{l}\text { After BORELL } \\
\text { 2017b, 62, Fig. } 3\end{array}$ \\
\hline & $\begin{array}{l}\text { redeges- } \\
\text { tus bust } \\
\text { intaglio }\end{array}$ & & $\begin{array}{l}\text { Óc Eo } \\
\text { (An Giang } \\
\text { Province, } \\
\text { Vietnam) }\end{array}$ & $\begin{array}{l}\text { Gand- } \\
\text { hāra? }\end{array}$ & $\begin{array}{l}\text { post- } 3^{\text {rd }} \text { century } \\
A D\end{array}$ & carnelian & Fig. 3,5 & $\begin{array}{l}\text { After BORELL } \\
\text { 2016, 110, Fig. } 11\end{array}$ \\
\hline & $\begin{array}{l}\text { bust of a } \\
\text { bearded } \\
\text { man } \\
\text { intaglio }\end{array}$ & & $\begin{array}{l}\text { Óc Eo } \\
\text { (An Giang } \\
\text { Province, } \\
\text { Vietnam) }\end{array}$ & $\begin{array}{l}\text { Gand- } \\
\text { hāra? }\end{array}$ & $\begin{array}{l}\text { post- } 3^{\text {rd }} \text { century } \\
A D\end{array}$ & carnelian & Fig. 3,4 & $\begin{array}{l}\text { After BORELL } \\
\text { 2016, 110, Fig. } 12\end{array}$ \\
\hline & $\begin{array}{l}\text { galloping } \\
\text { animal } \\
\text { intaglio }\end{array}$ & & $\begin{array}{l}\text { Phu Khao } \\
\text { Thong } \\
\text { (Ranong, } \\
\text { Thailand) }\end{array}$ & $?$ & $?$ & carnelian & Fig. 3,2 & $\begin{array}{l}\text { After KANGKED } \\
2009,88 .\end{array}$ \\
\hline & $\begin{array}{l}\text { elaphant } \\
\text { and human } \\
\text { heads } \\
\text { intaglio }\end{array}$ & & $\begin{array}{l}\text { Óc Eo } \\
\text { (An Giang } \\
\text { Province, } \\
\text { Vietnam) }\end{array}$ & $?$ & $\begin{array}{l}\text { post- } 1^{\text {st }}-2^{\text {nd }} \\
\text { century } A D ?\end{array}$ & carnelian & Fig. 3,6 & $\begin{array}{l}\text { After BORELL } \\
\text { 2016, 110, Fig. } 9\end{array}$ \\
\hline & $\begin{array}{l}\text { combina- } \\
\text { tion of hu- } \\
\text { man faces } \\
\text { intaglio }\end{array}$ & & $\begin{array}{l}\text { Óc Eo } \\
\text { (An Giang } \\
\text { Province, } \\
\text { Vietnam) }\end{array}$ & $?$ & $?$ & carnelian & Fig. 3,7 & $\begin{array}{l}\text { After BORELL } \\
\text { 2016, 110, Fig. } 10\end{array}$ \\
\hline \multirow{7}{*}{ 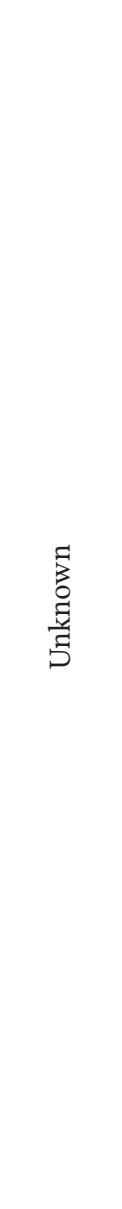 } & $\begin{array}{l}\text { satyr } \\
\text { intaglio } \\
\text { fragment }\end{array}$ & \multirow{7}{*}{ 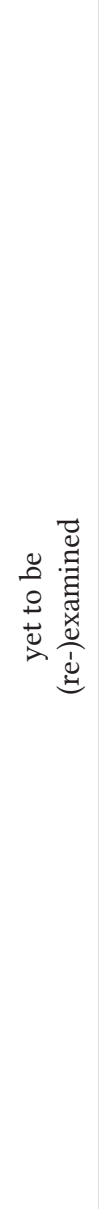 } & $\begin{array}{l}\text { Khlong } \\
\text { Thom (Krabi, } \\
\text { Thailand) }\end{array}$ & $\begin{array}{l}\text { Roman } \\
\text { Empire? }\end{array}$ & $\begin{array}{l}1^{\text {st }} \text { century } \\
\mathrm{BC}-1^{\text {st }} \text { century } \\
\mathrm{AD} \text { century? }\end{array}$ & - & Fig. 4,3 & $\begin{array}{l}\text { After BouzeK } \\
\text { - ONDŘEJOVÁ } \\
\text { 2009, 154, Fig. 1,1 }\end{array}$ \\
\hline & $\begin{array}{l}\text { Diomedes } \\
\text { holding the } \\
\text { Palladium } \\
\text { of Troy } \\
\text { intaglio }\end{array}$ & & $\begin{array}{l}\text { Khlong } \\
\text { Thom (Krabi, } \\
\text { Thailand) }\end{array}$ & $\begin{array}{l}\text { Roman } \\
\text { Empire? }\end{array}$ & $1^{\text {st }}$ century $\mathrm{AD} ?$ & - & Fig. 4,1 & $\begin{array}{l}\text { After WRIGHT } \\
2009,48\end{array}$ \\
\hline & $\begin{array}{l}\text { Aphrodite } \\
\text { and Ares } \\
\text { cameo }\end{array}$ & & $\begin{array}{l}\text { Khlong } \\
\text { Thom (Krabi, } \\
\text { Thailand) }\end{array}$ & $\begin{array}{l}\text { Roman } \\
\text { Empire? }\end{array}$ & $?$ & carnelian & Fig. 4,2 & $\begin{array}{l}\text { After WRIGHT } \\
2009,47\end{array}$ \\
\hline & $\begin{array}{l}\text { bust of a } \\
\text { woman/ } \\
\text { Hellenis- } \\
\text { tic king } \\
\text { intaglio }\end{array}$ & & $\begin{array}{l}\text { Khlong } \\
\text { Thom (Krabi, } \\
\text { Thailand) }\end{array}$ & $\begin{array}{l}\text { non- } \\
\text { Roman }\end{array}$ & $\begin{array}{l}\text { post- } 1^{\text {st }} \text { century } \\
\text { AD? }\end{array}$ & carnelian & Fig. 4,4 & $\begin{array}{l}\text { After BouzeK } \\
\text { - ONDŘEJOVÁ } \\
\text { 2009, 154, Fig. } 1,2\end{array}$ \\
\hline & $\begin{array}{l}\text { male bust } \\
\text { intaglio }\end{array}$ & & $\begin{array}{l}\text { Khlong } \\
\text { Thom (Krabi, } \\
\text { Thailand) }\end{array}$ & $\begin{array}{l}\text { non- } \\
\text { Roman }\end{array}$ & $?$ & carnelian & Fig. 4,6 & $\begin{array}{l}\text { After LIUCHAI- } \\
\text { CHAN 2019, } 62\end{array}$ \\
\hline & $\begin{array}{l}\text { Herakles } \\
\text { intaglio }\end{array}$ & & $\begin{array}{l}\text { Khlong } \\
\text { Thom (Krabi, } \\
\text { Thailand) }\end{array}$ & $\begin{array}{l}\text { non- } \\
\text { Roman }\end{array}$ & $?$ & - & Fig. 4,5 & $\begin{array}{l}\text { After Noonsuk } \\
\text { 2012, 53, Fig. } \\
\text { 1,16 }\end{array}$ \\
\hline & $\begin{array}{l}\text { profile } \\
\text { head with } \\
\text { diadem } \\
\text { cameo } \\
\text { fragment }\end{array}$ & & $\begin{array}{l}\text { Tha Chana } \\
\text { (Surat Thani, } \\
\text { Thailand) }\end{array}$ & $\begin{array}{l}\text { Roman } \\
\text { Empire? }\end{array}$ & $1^{\text {st }}$ century AD? & - & Fig. 5,1 & $\begin{array}{l}\text { After PoNGPA- } \\
\text { NICH 2013, } 108\end{array}$ \\
\hline
\end{tabular}


Krisztina HoppáL

\begin{tabular}{|c|c|c|c|c|c|c|c|c|}
\hline Category & Objects & Status & Provenance & Origin & $\begin{array}{c}\text { Hypothetical } \\
\text { dates }\end{array}$ & Material & $\begin{array}{l}\text { Illustra- } \\
\text { tion }\end{array}$ & Photocredit \\
\hline \multirow{13}{*}{$\begin{array}{l}5 \\
5 \\
\text { ह } \\
\text { है }\end{array}$} & $\begin{array}{l}\text { Bust of } \\
\text { a profile } \\
\text { head }\end{array}$ & \multirow{13}{*}{ 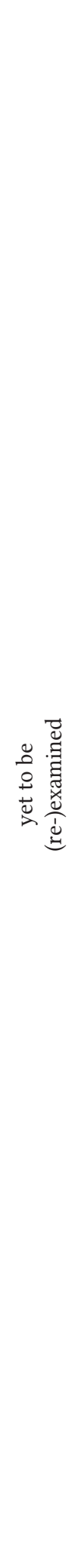 } & $\begin{array}{l}\text { Tha Chana } \\
\text { (Surat Thani, } \\
\text { Thailand) }\end{array}$ & $?$ & $?$ & - & Fig. 5,2 & $\begin{array}{l}\text { After WRIGHT } \\
\text { 2009, 56, Fig. } 4\end{array}$ \\
\hline & $\begin{array}{l}\text { bucolic } \\
\text { scene } \\
\text { intaglio }\end{array}$ & & $\begin{array}{l}\text { Phu Khao } \\
\text { Thong } \\
\text { (Ranong, } \\
\text { Thailand) }\end{array}$ & $?$ & $?$ & - & $\begin{array}{l}\text { Fig. } \\
5,5 a-b\end{array}$ & $\begin{array}{l}\text { After WRIGHT } \\
2009,52 \text {, Figs } \\
1-2\end{array}$ \\
\hline & $\begin{array}{l}\text { bust of } \\
\text { a profile } \\
\text { head } \\
\text { intaglio }\end{array}$ & & $\begin{array}{l}\text { Bang Kluai } \\
\text { Nok (Ranong } \\
\text { Thailand) }\end{array}$ & $?$ & $?$ & - & $\begin{array}{l}\text { Fig. } \\
5,3 a-b\end{array}$ & $\begin{array}{l}\text { After WRIGHT } \\
2009,57 \text {, Figs } \\
1-2\end{array}$ \\
\hline & $\begin{array}{l}\text { standing } \\
\text { horse with } \\
\text { column }\end{array}$ & & $\begin{array}{l}\text { Bang Kluai } \\
\text { Nok (Ranong } \\
\text { Thailand) }\end{array}$ & $?$ & $?$ & - & $\begin{array}{l}\text { Fig. } \\
6,4 a-b\end{array}$ & $\begin{array}{l}\text { After WRIGHT } \\
\text { 2009, 54, Figs } \\
1-2\end{array}$ \\
\hline & $\begin{array}{l}\text { winged } \\
\text { figure } \\
\text { intaglio }\end{array}$ & & $\begin{array}{l}\text { Bang Kluai } \\
\text { Nok (Ranong } \\
\text { Thailand) }\end{array}$ & $?$ & $?$ & - & Fig. 5,4 & $\begin{array}{l}\text { After PongPA- } \\
\text { NICH 2008, 36, } \\
\text { Fig. } 2\end{array}$ \\
\hline & $\begin{array}{l}\text { horse } \\
\text { and rider } \\
\text { intaglio }\end{array}$ & & $\begin{array}{l}\text { southern } \\
\text { Thailand }\end{array}$ & $\begin{array}{l}\text { non- } \\
\text { Roman? }\end{array}$ & $?$ & - & Fig. 6,1 & $\begin{array}{l}\text { After PoNGPA- } \\
\text { NICH 2019, } 250\end{array}$ \\
\hline & $\begin{array}{l}\text { galloping } \\
\text { horse and } \\
\text { rider }\end{array}$ & & $\begin{array}{l}\text { southern } \\
\text { Thailand }\end{array}$ & $\begin{array}{l}\text { non- } \\
\text { Roman? }\end{array}$ & $?$ & - & Fig. 6,2 & $\begin{array}{l}\text { After PongPA- } \\
\text { NICH 2019, } 267\end{array}$ \\
\hline & $\begin{array}{l}\text { walking } \\
\text { horse and } \\
\text { rider with } \\
\text { winged } \\
\text { helmet } \\
\text { intaglio }\end{array}$ & & $\begin{array}{l}\text { southern } \\
\text { Thailand }\end{array}$ & $\begin{array}{l}\text { non- } \\
\text { Roman? }\end{array}$ & $?$ & - & Fig. 6,5 & $\begin{array}{l}\text { After PongPA- } \\
\text { NICH 2019, } 267\end{array}$ \\
\hline & $\begin{array}{l}\text { Perseus } \\
\text { holding } \\
\text { Medu- } \\
\text { sa head } \\
\text { intaglio }\end{array}$ & & $\begin{array}{l}\text { Hmawza } \\
\text { (Bago, } \\
\text { Myanmar) }\end{array}$ & $\begin{array}{l}\text { Roman } \\
\text { Empire? }\end{array}$ & $\begin{array}{l}2^{\text {nd }}-3^{\text {rd }} \\
\text { century AD? }\end{array}$ & glass & Fig. 6,7 & $\begin{array}{l}\text { Di Crocco } \\
\text { 1996, 165, Fig. } 7\end{array}$ \\
\hline & $\begin{array}{l}\text { standing } \\
\text { female } \\
\text { figure }\end{array}$ & & $\begin{array}{l}\text { southern } \\
\text { Mynmar }\end{array}$ & $?$ & $?$ & - & Fig. 6,6 & $\begin{array}{l}\text { After PongPA- } \\
\text { NICH 2019, } 266\end{array}$ \\
\hline & $\begin{array}{l}\text { standing } \\
\text { horse with } \\
\text { column }\end{array}$ & & $\begin{array}{l}\text { southern } \\
\text { Mynmar }\end{array}$ & $\begin{array}{l}\text { non- } \\
\text { Roman? }\end{array}$ & $?$ & - & Fig. 6,3 & $\begin{array}{l}\text { After PongPA- } \\
\text { NICH 2019, } 266\end{array}$ \\
\hline & male figure & & $\begin{array}{l}\text { Phum Snay } \\
\text { (Banteay } \\
\text { Meanchey } \\
\text { Province, } \\
\text { Cambodia) }\end{array}$ & $\begin{array}{l}\text { non- } \\
\text { Roman? }\end{array}$ & $?$ & - & Fig. 6,8 & $\begin{array}{l}\text { After LAPTEFF } \\
\text { 2016, 316, Fig. } 27\end{array}$ \\
\hline & $\begin{array}{l}\text { female } \\
\text { figure }\end{array}$ & & $\begin{array}{l}\text { Lop Buri } \\
\text { province, } \\
\text { Thailand }\end{array}$ & $\begin{array}{l}\text { non- } \\
\text { Roman }\end{array}$ & $?$ & carnelian & Fig. 6,9 & $\begin{array}{l}\text { After BHUMAD- } \\
\text { HON 2019, } 184\end{array}$ \\
\hline
\end{tabular}




\section{References}

Adams, N. 2011: The garnet Millenium: The role of seal stones in garnet studies. In: Entwistle, Ch. - Adams, N. (eds): Gems of heaven. Recent research on engraved gemstones in late Antiquity. London, 10-24.

Aung Thaw 1978: Historical sites in Burma. Rangoon.

BellinA, B. 1998: La formation des reseaux d'echanges reliant l'Asie du Sud et l'Asie du Sud-Est a travers le

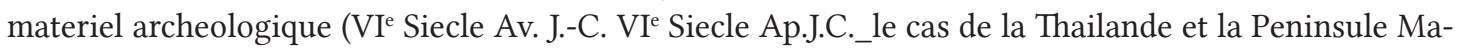
laise). The fournal of the Siam Society, 86:1-2, 89-105.

BellinA, B. 2003: Beads, social change and interaction between India and South-East Asia. Antiquity 77:296, 285-297. DOI: 10.1017/S0003598X00092279

BellinA, B. 2014: Maritime Silk Roads' Ornament Industries: Socio-political Practices and Cultural Transfers in the South China Sea. Cambridge Archaeological fournal 24:3, 345-377. DOI: 10.1017/S0959774314000547

BellinA, B. 2017a: The Beginning of the Urban Narratives in South and Southeast Asia. In: Bellina, B. (ed.): Khao Sam Kaeo: a late prehistoric early port-city between the Indian Ocean and the South China Sea. Paris, 625-648.

BellinA, B. (ed.) 2017b: Khao Sam Kaeo: a late prehistoric early port-city between the Indian Ocean and the South China Sea. Paris.

BellinA, B. - Glover I. 2004: The Archaeology of Early Contact with India and the Mediterranean World, from the Fourth Century BC to the Fourth Century AD. In: Glover, I. - Bellwood, P. (eds): Southeast Asia: From Prehistory to History. London, 68-88.

Bellina, B. - Silapanth, P. - Chaisuman, B. - Allen, J. - Bernard, V. - Borell, B. - Bouvet, P. - Castillo, C. Dussubieux, L. - Malakie, J. - Perronnet, S. - Pryce, T. O. 2014: The development of coastal polities in the upper Thai-Malay Peninsula of the late first millennium BCE and the inception of the long-lasting economic and cultural exchange between the East of the Indian Ocean and the South China Sea. In: Revire, N. - Murphy, S. A. (eds): Before Siam Was Born: Essays in art and archaeology. Bangkok, 68-89.

Bourdonneau, É. 2003: The Ancient Canal System of the Mekong Delta. Preliminary Report. In: Karlstrôm, A. - Kàllén, A. (eds): Fishbones and Glittering Emblems. Southeast Asian Archaeology 2002. Stockholm, 257-270.

BourdonneAu, É. 2010: Réhabiliter le Funan. Óc Eo ou la première Angkor. Bulletin de l'Ecole française d'Extrême-Orient 94, 111-158. DOI: 10.3406/befeo.2007.6067

Borell, B. 2008: Some western imports assigned to the Oc Eo period reconsidered. In: Pautreau, J.-P. - Coupey, A.-S. - Zeitoun, V. - Rambault, E. (eds): From homo erectus to the living traditions. Choice of papers from the 11th International Conference of the European Association of Southeast Asian Archaeologists, (Bougon 2006). Chiang Mai, 167-174.

Borell, B. 2014: The Power of Images. Coin Portraits of Roman Emperors on Jewellery Pendants in Early Southeast Asia. Zeitschrift für Archäologie Außereuropäischer Kulturen 6, 7-43.

Borell, B. 2015: Isthmus von Kra: Im Schnittpunkt maritimer Routen. In: Tjoa-Bonatz, M. L. - Reinecke, A. (eds): Im Schatten von Angkor. Darmstadt, 45-53.

Borell, B. 2016: Vietnam und die maritime Seidenstraße in den frühen Jahrhunderten n. Chr. In: LWL-Museum für Archäologie Herne et al. (eds): Schätze der Archäologie Vietnams. Mainz, 125-135.

Borell, B. 2017a: Gemstones in Southeast Asia and Beyond: Trade along the Maritime Networks. In: Hilgner A. - Greiff, S. - Quast, D. (eds): Gemstones in the first Millennium AD: Mines, Trades, Workshops and Symbolism. RGZM Tagungen 30. Mainz, 21-44.

Borell, B. 2017b: Herakles on an Intaglio Seal Found at Phu Khao Thong in the Upper Thai-Malay Peninsula. Zeitschrift für Archäologie Außereuropäischer Kulturen 7, 59-82. 
Borell, B. 2017c: Stone Seals and Intaglios from Khao Sam Kaeo, with contributions by Harry Falk. In: Bellina, B. (ed.): Khao Sam Kaeo: An Early Port-City between the Indian Ocean and the South China Sea. Paris, $587-618$.

Borell, B. 2019: Roman gold coin found in Peninsular Thailand. In: Pongpanich, B. - Thinapong, S. (eds): Suvarnabhumi: Land of Gold: The new finding for Suvarnabhumi Terra Incognita. Bangkok, 58-66.

Borell, B. - Bellina, B. - Chaisuwan, B. 2014: Contacts between the Upper Thai-Malay Peninsula and the Mediterranean World. In: Revire, N. - Murphy S. A. (eds): Before Siam: Essays in art and archaeology. Bangkok, 99-117.

Bouzek, J. - OndřEjovÁ, I. 2009: Roman Gems from the Klong Thong [sic!] District of the Krabi Province in Thailand (Ř́mské gemy z okresu Klong Thong v provincii Krabi v Thajsku). Graecolatina Pragensia 22, $147-154$.

Bouzek, J. - OndřEjovÁ, I. 2010: Other Roman Imports from the Klong Thong [sic!] District of the Krabi Province in Thailand. Graecolatina Pragensia 23, 7-14.

Brancaccio, P. 2005: Perceptions of "Westerners" in Sātavāhana Times: The Archaeological Evidence. In: Jarrige, C. - Lefèvre, V. (eds): South Asian Archaeology 2001. Proceedings of the Sixteenth International Conference of the European Association of South Asian Archaeologists, held in Collège de France, Paris, 2- 6 fuly 2001. Paris, 401-406.

Bronson, B. 1990: Glass and beads at Khuan Lukpad, Southern Thailand. In: Glover, I. - Glover, E. (eds): Southeast Asian Archaeology. British Archaeological Reports - International Series 561. Oxford, 213-229.

Bhumadhon, P. 2019: Suvarnabhumi: Transpeninsular Land between the Gulf of Martaban and the Gulf of Tonkin. In: Pongpanich, B. - Thinapong, S. (eds): Suvarnabhumi: Land of Gold: The new finding for Suvarnabhumi Terra Incognita. Bangkok, 179-190.

Carter, A. K. - Dussubieux, L. 2016: Geologic provenience analysis of agate and carnelian beads using laser ablation-inductively coupled plasma-mass spectrometry (LA-ICP-MS): A case study from Iron Age Cambodia and Thailand. Journal of Archaeological Science: Reports 6, 321-331. Dor: 10.1016/j.jasrep.2016.02.025

Chaisuwan, B. 2011: Early Contacts between India and the Andaman Coast in Thailand from the Second Century BCE to Eleventh Century CE. In: Manguin, Y.-P. - Mani, A. - Wade. G. (eds): Early Interactions between South and Southeast Asia Reflections on Cross-Cultural Exchange. Pasir Panjang-New Delhi, 83-112. DOI: 10.1355/9789814311175-007

CHAISUWAN, B. บุณยฤทธ็ ฉายสุวรรณ, NAIYAWAT, R. เรไร นัยวัฒน์ 2009 (2552): สงขลา, ทุ่งตึกจุดเชือมโยงเส้นทาง สายไหมทางทะเล. Sŏng-klăa, Tûng Dtèuk jùt chêuuam yohng sên taang săai măi taang tá-lay. Thung Tuk: a settlement linking together the maritime Silk Route. Hatyai.

CeEdès, G. 1947: Fouilles en Cochinchine: Le Site de Go Oc Eo, Ancien Port du Royaume de Fou-nan. Artibus Asiae 10:3, 193-199. DOI: 10.2307/3248251

Cовв, M. A. 2018: Rome and the Indian Ocean Trade from Augustus to the Early Third Century CE. Leiden.

Совв, M. A. - Mitchell, F. 2019: Eros at Junnar: reconsidering a piece of Mediterranean art. Greece and Rome 66:2, 203-226. DOI: 10.1017/S0017383519000044

Cravinho, G. 2017: Roman Engraved Gems in the National Archaeological Museum in Lisbon. Studies in Ancient Art and Civilisation 21, 173-245. DoI: 10.12797/SAAC.21.2017.21.09

Đặng V. T. - Võ V. S. 2017: Recognition of Oc Eo Culture Relic in Thoai Son Districtan Giang Province, Vietnam. American Academic Scientific Research fournal for Engineering, Technology, and Sciences 36:1, 271-293.

Di Crocco, V. M. 1996: Reference and Artifacts Connecting the Myanmar Area with Western and Central Asia and China Proper via the Ancient Southwestern Silk Route from ca. the 3rd Century B.C. to the 13th Century C.E. In: Chutiwongs, N. - Ray, H. P. - Glover, I. C. (eds): Ancient Trades and Cultural Contacts in Southeast Asia. Bangkok, 161-180. 
Dussubieux, L. - Bellina, B. - Win Hsan Oo - U Maung Sun Win - Htet Myet Tut - Kalayar Myat Myat Htwe - Khinsandar Kyaw 2020: First elemental analysis of glass from Southern Myanmar: Replacing the region in the early Maritime Silk Road. Archaeological and Anthropological Sciences 12:139. DOI: 10.1007/s12520-020-01095-1

Dussubieux, L. - Bellina, B. 2017: Glass from an Early Southeast Asian Producing and Trading Centre. In: Bellina, B. (ed.): Khao Sam Kaeo: An Early Port-City between the Indian Ocean and the South China Sea. Paris, 425-461.

El-Khachab, A. M. 1963: A Collection of Gems from Egypt in Private Collections. The fournal of Egyptian Archaeology 49, 147-156. DOI: 10.1177/030751336304900115

Forbes, B. A. 1995: The Princeton Art Museum's collection of classical and classicizing engraved gemstones. Record of the Art Museum, Princeton University 54:1, 23-29. DoI: 10.2307/3774715

GeszTELyi T. 1978: Ifjú szatírportrék gemmákon. A Debreceni Déri Múzeum Évkönyve 58, 167-173.

Gesztelyi T. 2001: Gemmák és gyürük Brigetióból. Gemstones and Finger Rings from Brigetio. A Kuny Domokos Múzeum gyűjteményei 6. Tata.

Gesztelyi T. 2005: Antik gemmaörökségünk. Candidate thesis, Hungarian Academy of Sciences, Debrecen.

Glover, I. C. 1990: Early trade between India and Southeast Asia: a link in the Development of a World Trading System. Hull.

Glover, I. C. 1996a: The Archaeological Evidence for Early Trade between India and Southeast Asia. In: Reade, J. (ed.): The Indian Ocean in Antiquity. London, 365-400.

Glover, I. 1996b: The Southern Silk Road: Archaeological Evidence for Early Trade between India and Southeast Asia. In: Chutiwongs, N. - Ray, H. P. - Glover, I. C. (eds): Ancient Trades and Cultural Contacts in Southeast Asia. Bangkok, 57-94.

Glover, I. C. - Bellina, B. 2001: Alkaline Etched Beads East of India in the Late Prehistoric and Early Historic Periods. Bulletin de l'École française d'Extrême-Orient 88, 191-215. DOI: 10.3406/befeo.2001.3513

HÀ, V. T. 1986: Oc Eo: Endogenous and exogenous elements. Vietnam Social Sciences 1-2:7-8, 91-101.

HoppáL, K. 2015a: Contextualizing the comparative perceptions of Rome and China through written sources and archaeological data. $\mathrm{PhD}$ dissertation, Eötvös Loránd University.

HoppáL, K. 2015b: Contextualizing the comparative perceptions of Rome and China through written sources and archaeological data. Dissertationes Archaeologicae 3/3, 285-301. DOI: 10.17204/dissarch.2015.285

Hoppál, K. 2016: Contextualising Roman-related Glass Artefacts in China. An Integrated Approach to Sino-Roman Relations. Acta Archaeologica Academiae Scientiarum Hungaricae 67, 99-114. DOI: 10.1556/072.2016.67.1.3

Hoppál, K. - VidA, I. - Adhityatama, S. - Lu, Y. 2018: All that glitters is not Roman'. Roman coins discovered in East Java, Indonesia. A study on new data with an overview on other coins discovered beyond India. Dissertationes Archaeologicae 3/6, 461-492. DoI: 10.17204/dissarch.2018.461

Hoppál, K. - Bellina, B. - Dussubieux, L. (forthcoming): Links between the Mediterranean world, South Asia, Southeast Asia and China from the late 1st millennium BC to the early first centuries AD. Proceedings of Alexandria the cosmopolis: a global perspective, Centre d'études alexandrines, December 2-5, 2019, Alexandria, Egypt. Études Alexandrines. Forthcoming.

Hung, Hs.-Ch. - Bellwood, P. 2010: Movement of Raw Material and Manufactured Goods Across the South China Sea after 500 BCE: From Taiwan to Thailand, and Back. In: Bellina, B. - Bacus, E. A. - Pryce, T. O. - Wisseman Christie, J. (eds): 50 Years of Archaeology in Southeast Asia. Essays in Honour of Ian Glover. Bangkok, 234-245.

JacQ-Hergoualc'H, M. 2002: The Malay Peninsula. Crossroads of the Maritime Silk Road (100 BC-1300 AD). Handbook of Oriental Studies 3/13. Leiden-Boston-Cologne. DoI: 10.1163/9789047400684 
KANGKED, N. นฤมล กางเกตุ 2009: เครืองประดับทีพบในแหล่งโบราณคดีภูเขาทองและบริเวณใกล้เคียงในจังหวัดระนอง Krêuuang bprà-dàp têe póp nai làeng boh-raan ká-dee Poo Kăo Tong láe bor-rí-wen glâi kiiang nai jangwàt Rá-nong - The ornaments discovered at Phu Khao Thong archaeological sites and vicinities in, Ranong Province. Master Thesis Silpakorn University, Thailand.

Krairiksh, P. 2012: The Roots of Thai Art. Bangkok.

LAPTEFF S.V. 2007: Phum Snay site and the birth of Hinduist kingdoms in Indochina. Fournal of Indian Ocean Archaeology 4, 67-77.

Lapteff S.V. 2013: Early Iron Age Burial Practices of the Ancient Khmer People: The Phum Snay Necropolis, Northwestern Cambodia. Archaeology Ethnology and Anthropology of Eurasia 41:2, 137-145. DOI: 10.1016/j.aeae.2013.11.013

LaptefF S.V. 2016: On Post-Hellenistic Influence in South-East Asia Based on New Materials Recently Found in Southern Thailand and around Tonle Sap Lake in Cambodia. Ancient Civilizations from Scythia to Siberia 22, 295-320. DOI: 10.1163/15700577-12341304

LÊ, T. L. 2015: Hindu Beliefs and the Maritime Network in Southern Vietnam during the Early Common Era. Journal of Indo-Pacific Archaeology 39, 1-17. DOI: 10.7152/jipa.v39i0.14748

LÊ, T. L. 2018: Indian-Southeast Asian Contacts and Cultural Exchanges: Evidence from Vietnam. In: Saran, S. (ed.): Cultural and Civilisational Links between India and Southeast Asia. Singapore 107-127. DoI: 10.1007/978-981-10-7317-5_7

LIUCHAICHāN, B. บัณฑิต ลีวชัยชาญ 2019 (2562): มรดกวัฒนธรรม ภาคใต. - Mor-rá-dòk wát-tá-ná-tam pâak dtai Southern Cultural Heritage. Bangkok.

Malleret, L. 1951: Aperçu de la glyptique d'Oc-èo. Bulletin de l'École française d'Extrême-Orient Année 44:1, 189-200. DOI: 10.3406/befeo.1951.5045

Malleret, L. 1959-1963: L’Archéologie du Delta du Mékong. Vols 1-4. Paris.

Manguin, P.-Y. 2004: The Archaeology of Early Maritime Polities of Southeast Asia. In: Glover, I. - Bellwood, P. (eds): Southeast Asia: from Prehistory to History. London-New York, 282-313.

Manguin, P.-Y. 2009: The Archaeology of Funan in the Mekong River Delta: The Oc Eo Culture of Vietnam. In: Tingley, N. (ed.): Arts of Ancient Vietnam: From River Plain to Open Sea. Houston, 100-118.

Mastrocinque, A. 2011: The Colours of Magical Gems. In. In: Entwistle, Ch. - Adams, N. (eds): Gems of heaven. Recent research on engraved gemstones in late Antiquity. London, 62-74.

Middleton, S. E. 2005: Intaglios, Cameos, Rings and Related Objects from Burma and Fava - The White Collection and a Further Small Private Collection. British Archaeological Reports - International Series 1405. Oxford.

Miksic, J. N. - Geok Yian Goh 2016: Ancient Southeast Asia. New York. Dor: 10.4324/9781315641119

Moore, E.H. 2009: Place and space in early Burma: A new look at 'Pyu Culture'. Journal of the Siam Society 97, 101-128.

NANJING BowUYUAN 南京博物元院 1981: 江苏邗江甘 泉二号汉墓 (Jiangsu Hanjiang Ganquan Erhao Han$\mathrm{mu}-$ Tomb no. 2 in Ganquan, Hanjiang, Jiangsu). 文物 Wenwu 11, 1- 10.

Noonsuk, W. 2012: Archaeology And Cultural Geography Of Tambralinga In Peninsular Siam. PhD Dissertation, Cornell University, Ithaca, NY.

O’Reilly, D. J. W. - Pheng Sytha 2001: Recent excavations in northwest Cambodia. Antiquity 75:288, 265266. DOI: $10.1017 / \mathrm{S} 0003598 \mathrm{X} 00060865$

O'Reilly, D. J. W. - Thuy Chanthourn - Domett, K. 2004: A preliminary report on the excavation of an Iron Age cemetery at Phum Snay, Banteay Meanchey, Cambodia, 2003. Udaya: Fournal of Khmer Studies $5,219-225$.

Pedroni, L. 2018: Amethystus: Ancient Properties and Iconographic Selection. In: Matetić Poljak, D. Marasović, K. (eds): Izvornik: ASMOSIA XI. Interdisciplinary Studies on Ancient Stone. Proceedings of the XI International Conference of ASMOSIA, Split 2015. Split, 167-171. DoI: 10.31534/XI.asmosia.2015/01.15 
PongPANICH, B. บัญชา พงษ์พานิช 2008: รอยลูกปัด. Beads\&Beyond. Selected Rare Beads an Objects in the Collection of Suthi Rattana Foundation. Exhibition Catalogue. Bangkok.

PongPANich, B. 彭帕寧, 班查 2013: 定要收藏的古珠.天珠珍貴圖鑑 - Dingyao shoucangde guzhu - Tianzhu zhengui tujian - Beyond beads. Xinbeishi.

Pongpanich, B. 2019: Suvarnabhumi: The Preliminary Conclusion (สุวรรณภูมิ มีจริง ? อยู่ทีไหน ? เป็นอย่างไร ? บทสรุปเบืองต้นจากการทบทวน ประมวลความรู้ - Sù-wan-ná-poom mee jing yòo têe năi bpen yàang rai bòt sà-rùp bêuuang dtôn jàak gaan tóp tuuan bprà-muuan kwaam róo). In: Pongpanich, B. - Thinapong, S. (eds): Suvarnabhumi: Land of Gold: The new finding for Suvarnabhumi Terra Incognita. Bangkok, 219-278.

Richter, G. M. A. 1968: The Subjects on Roman Engraved Gems and their Derivation, Style and Meaning. Revue Archéologique, Nouvelle Série, Fasc. 2, Études de sculpture antique offertes à Jean Charbonneaux 2, 279-286.

Rosenfeld, A. - Dvoracher, M. - Amorai-Stark, S. 2003: Roman Wheel-cut Engraving, Dyeing and Painting Microquartz Gemstones. Fournal of Archaeological Science 30:2, 227-238. Dor: 10.1006/jasc.2002.0829

Sena Chiesa, G. 1966: Gemme del Museo Nazionale di Aquileia. Padua.

Srisuchat, A. - Buransiri, B. - Khanthakan, P. - Chaiseno, B. 1987: An Archaeological Visit to the South. In: Seminar in Prehistory of Southeast Asia. SPAFA Final Report. Bangkok, 345-363.

SRISUChat, A. 1998: A Proposed Outline of the Chronology of Early History in Thailand: Dating and Re-analysis of Data from Recently Excavated Sites in Thailand. In: Klokke, M. J. - de Bruijn, T. (eds): Southeast Asian Archaeology 1986. Proceedings of the 6th International Conference of the European Association of Southeast Asian Archaeologists Leiden, 2-6 September 1996. Hull, 99-115.

Stargardt J. 1990: The Ancient Pyu of Burma. Singapore.

Thein Lwin - Win Kyaing - Stargardt, J. 2014: The Pyu civilization of Myanmar and the city of Śri Kșetra. In: J. Guy (ed.): Lost Kingdoms: Hindu-Buddhist Sculpture of Early Southeast Asia. New York-Bangkok, 63-68.

Theunissen, R.- Grave, P. - Bailey, G. 2000: Doubts on diffusion: challenging the assumed Indian origin of Iron Age agate and carnelian beads in South-east Asia. World Archaeology 32:1, 84-105. Dor: $10.1080 / 004382400409907$

Thoresen, L. 2017: Archaeogemmology and Ancient Literary Sources on Gems and their Origins. In: Hilgner, A. - Greiff, S. - Quast, D. (eds): Gemstones in the first Millennium AD: Mines, Trades, Workshops and Symbolism. RGZM Tagungen 30. Mainz, 155-218.

VALLIBHOTAMA, S. ศรีศักร วัลลิโภดม 1988: ความก้าวหน้าของโบราณคดีในภาคใต้: การประเมินเพือสนองภาพรวม (Kwaam gâao nâa kŏng boh-raan: Ká-dee nai pâak dtâi gaan bprà-mern pêuua sà-nŏng pâap-pá-ruuam Development of Archaeology in the South: A Comprehensive Evaluation). วารสารเมืองโบราณ - Muang Boran fournal 14:3, 39-50.

VerAPRASERT, M. 1987: Khlong Thom: An Ancient Bead Manufacturing Location and an Ancient Entrepôt. In: Seminar in Prehistory of Southeast Asia, SPAFA Final Report, SEAMO Project in Archaeology and Fine Arts. Bangkok, 323-331.

Veraprasert, M. 1992: Klong Thom: An Ancient Bead-Manufacturing Location and an Ancient Entrepôt. In: Glover, I. - Suchitta, P. - Villiers, J. (eds): Early metallurgy, trade and urban centres in Thailand and Southeast Asia. Bangkok, 149-162.

Wright, M. ไรท์, ไมเคิล 2009 (2552): กรีก-โรมัน ในอุษาคเนย์ - Grèek Roh-man nai Ù-săa ká-nay - Greco-Romans in Southeast. Bangkok.

(C) 2022 The Author(s).

This is an open-access article distributed under the terms of the Creative Commons Attribution-Non Commercial 4.0 International Licence (CC BY-NC 4.0). 
